\title{
THE HISTORICAL DEVELOPMENT OF UNDERGROUND COAL GASIFICATION
}

D. Olness

D. W. Gregg

June $30,19.77$

\section{MST}

Prepared for U.S. Energy Research \& Development

And Administration under contract No. W-7405-Eng-48

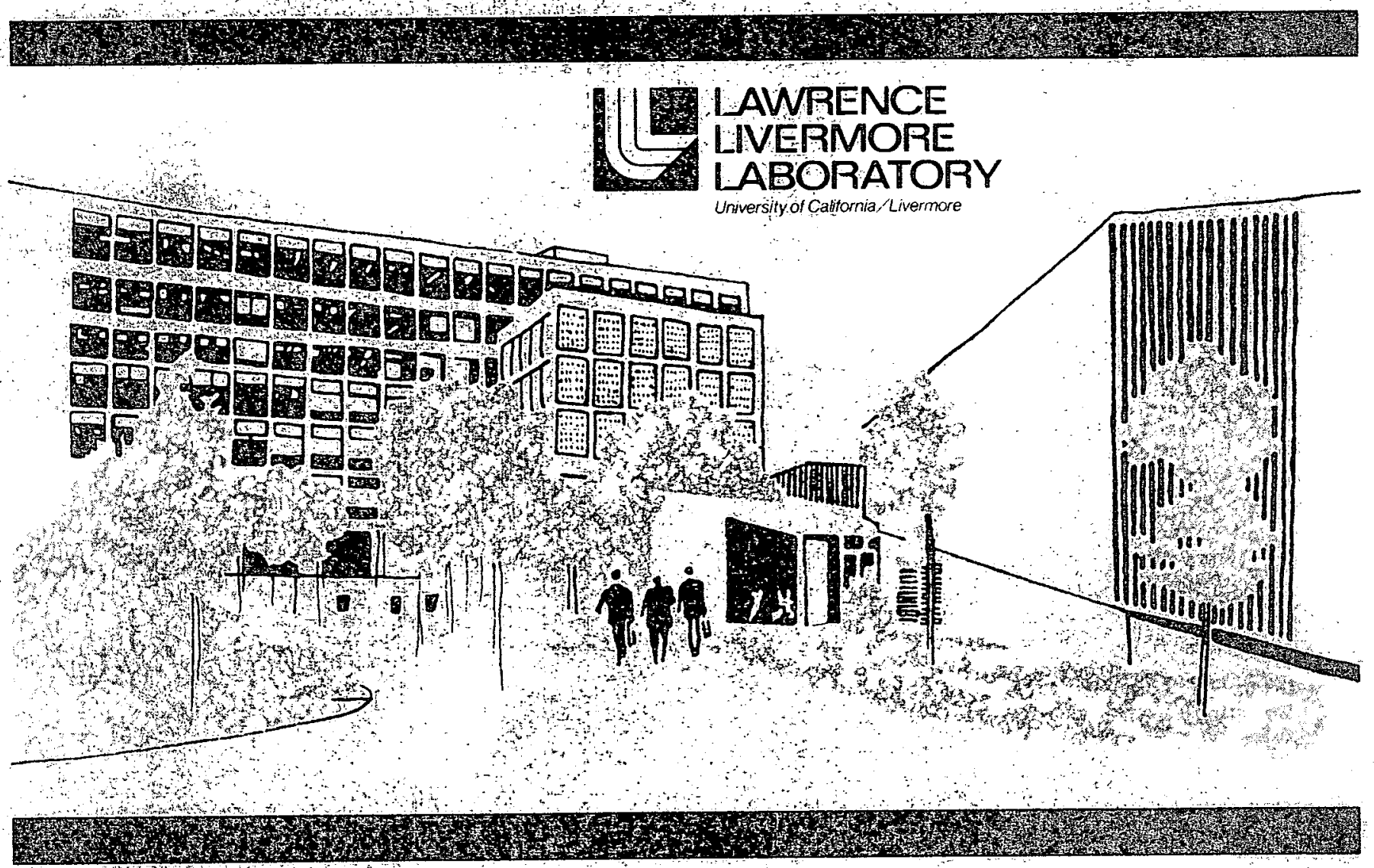




\section{DISCLAIMER}

This report was prepared as an account of work sponsored by an agency of the United States Government. Neither the United States Government nor any agency Thereof, nor any of their employees, makes any warranty, express or implied, or assumes any legal liability or responsibility for the accuracy, completeness, or usefulness of any information, apparatus, product, or process disclosed, or represents that its use would not infringe privately owned rights. Reference herein to any specific commercial product, process, or service by trade name, trademark, manufacturer, or otherwise does not necessarily constitute or imply its endorsement, recommendation, or favoring by the United States Government or any agency thereof. The views and opinions of authors expressed herein do not necessarily state or reflect those of the United States Government or any agency thereof. 


\section{DISCLAIMER}

Portions of this document may be illegible in electronic image products. Images are produced from the best available original document. 


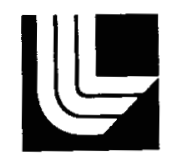

$\mathrm{UC}-90 \mathrm{C}$

\title{
LAWRENCE LIVERMORE I_ABORATORY
}

\author{
University of California/Livermore, California/94550
}

\section{UCRL- 52283 \\ THE HISTORICAL DEVELOPMENT OF UNDERGROUND COAL GASIFICATION}

\author{
D. Olness \\ D. W. Gregg
}

MS. date: June 30,1977

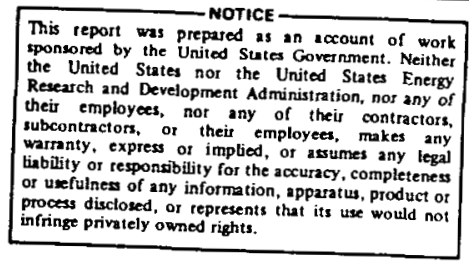




\section{Table of Contents}

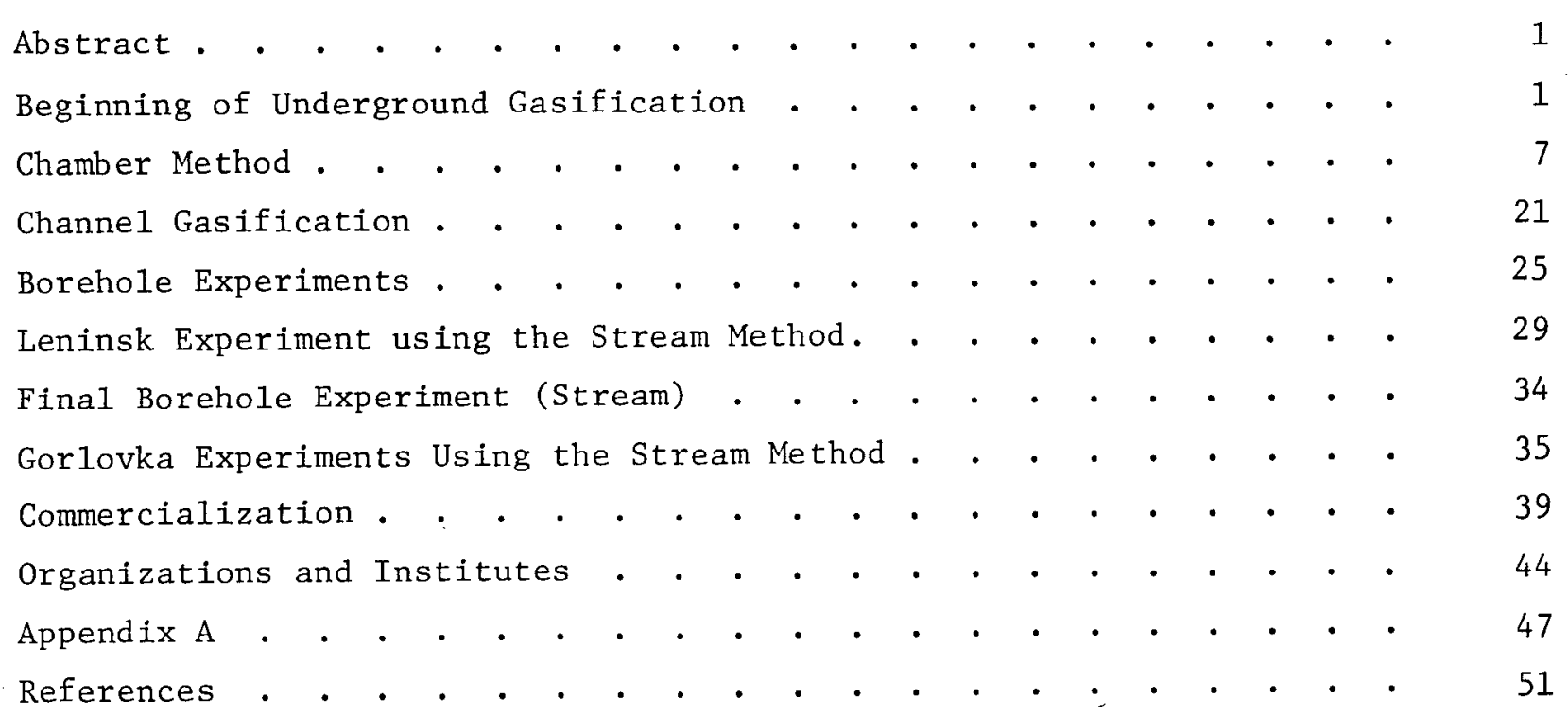




\title{
THE HISTORICAL DEVELOPMENT OF UNDERGROUND COAL GASIFICATION
}

\begin{abstract}
The development of underground were important in helping to alter coal gasification is traced through a discussion of the significant, early experiments with in situ gasification. Emphasized are the features of each experiment that and refine the process to its present state. Experimental details, coal characteristics, and gasification data are supplied for many of the experiments.
\end{abstract}

\section{Beginning of Underground Gasification}

Coal has been used as a source of energy for nearly 3000 years. Although mined in Europe as early as the 13th century, it was not a highly desirable fuel because of its toxic combustion products. Coal did not become an important source of fuel until the beginning of the Industrial Revolution about 300 years later, and was first used in gas production during the. late 18th century. Early production was used primarily for lighting, but.. as gasification techniques improved, application grew wider. By the 19th. century the conversion of coal to gas was a well established commercial process.

The German scientist Sir William Siemens was probably the first to suggest gasifying coal underground. 1,2 Siemens described the merits of an invention he shared with his brother in a speech entitled "The Regenerative Gas Furnace as Applied to the Manufacture of Cast Steel," delivered before the Fellows of the Chemical Society of London on May 7, $1868 .^{3}$ He noted that gas production directly in the mine could be very efficient because it could occur any distance from the furnaces so long as it happened at a lower level. By burning the coal and waste in situ, the energy content of the wasted coal would be used. "In rising to the mouth of the pit," Siemens suggested, "the gas would acquire sufficient pressure to send it through several miles of culvert" to the steel furnaces, eliminating the need for gas transport pumps. ${ }^{3}$

The famous Russian scientist Dmitriy Ivanovich Mendeleyev observed 
many fires in underground coal mines caused by spontaneous ignition.

"Regarding the fires in beds of hard coal," he reported, "it appears to me that they could be utilized by controlling and directing them in such a way that the combustion takes place as in a generator, i.e., with a limited access of air. Then carbon monoxide must be formed and generator gas be produced in the bed. Having drilled a number of holes into the seam, one of them should be used for the introduction - or even injection - of blast and the other for the discharge - or even extraction - of the fue 1 gasses". 5 In 1888,6 Mendeleyev wrote the following about the coal in the Donets basin: "...with time, probably, there will even come an epoch when coal will not be extracted from the ground, but will be converted into fuel gases there in the ground and distributed over long distances through pipes." 7

Throughout the rest of his life, Mendeleyev considered the problem of underground gasification. In 1897 he repeated his earlier prediction in a treatise entitled Foundations of the Manufacturing Industry. ${ }^{7}$ He wrote, "In my opinion, in the future we may expect a very great lowering in the cost of coal fuel only if it is converted underground, so far as possible

*Blast is the conventional Soviet term for the injected reactant (oxygen bearing) gas. in the seams themselves (without mining them out) into generator gases which are then distributed through pipes, in which I do not see any fundamental difficulty." In 1909, a British patent ${ }^{8}$ was granted to an American, A. G. Betts, whose stated object was "to obviate these sacrifices [extensive labor costs and loss of life underground] and also to provide for utilization of coal seams too thin or too poor for commerical use by present methods." Betts' patent presented two different methods for in situ coal gasification. In the first, which is very similar to Mendeleyev's suggestion, "Two shafts, or a shaft and borehole, may be provided in the coal seam, and an air passage through the seam provided, either by driving from one shaft to the other or from the shaft to the borehole which, if not already existing, is sunk to the workings. A fire is started at the bottom of one shaft and a supply of air pumped down and water or steam also supplied, when gas analagous to producer gas comes out of the other shaft, and can be used for running gas engines, smelting works, glass works, firing boilers, etc.

"For the greatest economy of fuel in making gas, water should be brought to the burning coal as well as air. If sufficient water is not supplied by natural agencies, it may be passed 
in the gaseous state with the air supply" 8 (see Fig. 1, reproduced from Betts' patent). Betts also suggested using multiple channels that provided better resource recovery and a means of obtaining gases of either variable or constant heating values "by operating a number of subterranean fires in different stages of completion." This early patent is remarkably complete, considering in detail, for example, such problems as subsidence.

Betts proposed a plan for mining a channe1 under the seam that was to be gasified. From this channel bore- holes would be drilled upward to supply the blast to the bottom of the seam. In Bett's patent, quite a different method is also described, "in which it is required only to use one borehole to the coal. After the borehole is completed, a pipe is let down to the coal through the borehole for a supply of air, the coal ignited and thereafter a current of air forced in, and gas taken out. After so large an area is burned out that the action is not satisfactory, another borehole may be let down to near the edge of the burned area, through which air is supplied thereafter instead of through

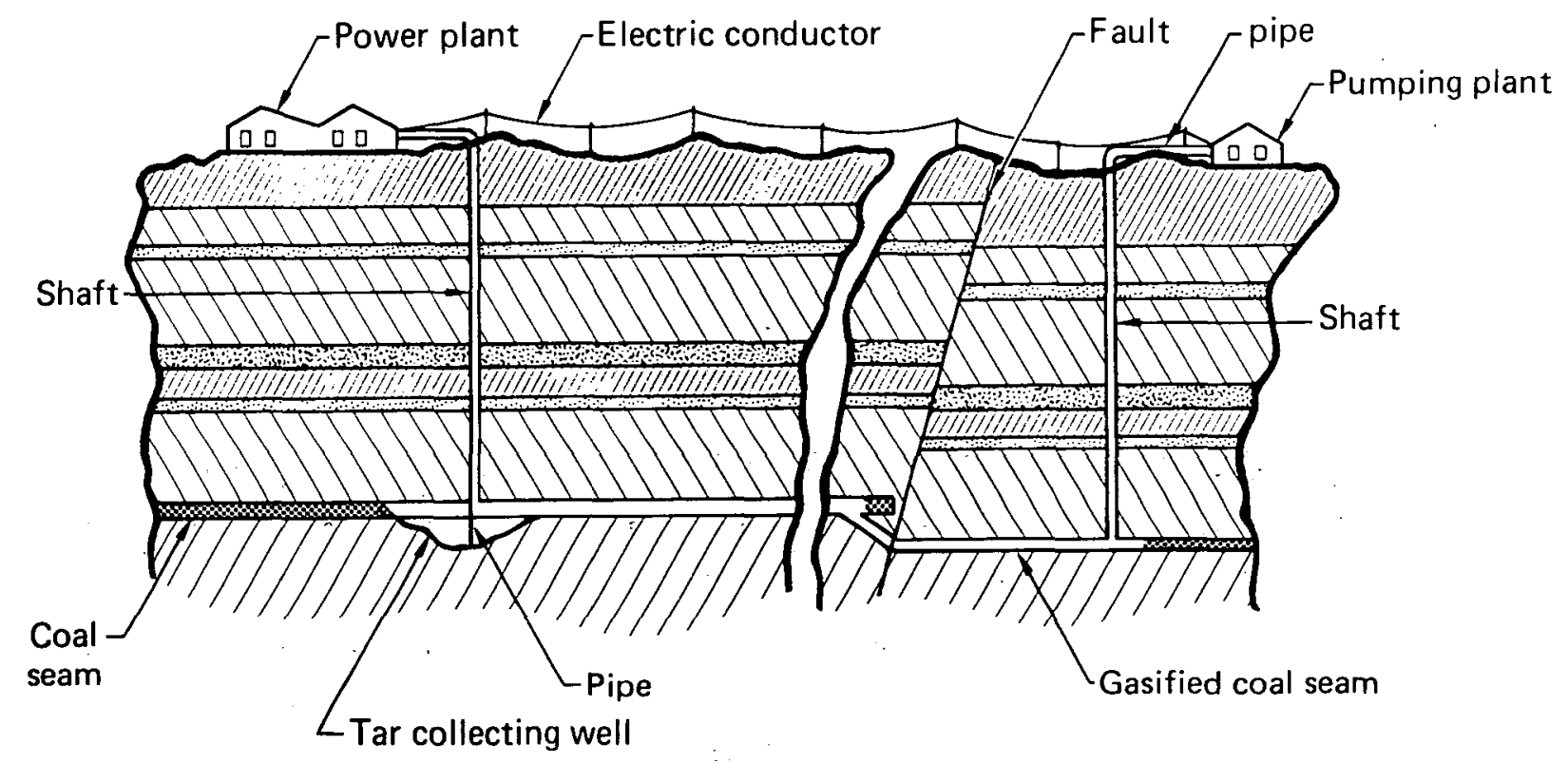

Fig. 1. Reproduction of Bett's patent specifications. The coal seam is faulted. The power plant supplied electricity through the electric conductor to the pumping plant, which pumped air into the pipe and down the shaft. The air is then forced from the shaft into the coal seam where gas is produced and forced up the other shaft into the power plant where it is cleaned and used to produce electricity. (The power plant may also contain a gas cleaning apparatus, gas engine, and dynamo.) A well collects tar that is pumped out through a pipe. 
the first mentioned means, until that too ceases to work we11, when other holes may be put down." 8

About 1910 , a special committee of Britain's leading scientists was formed to investigate "national energy resources."1,2 They made several proposals: the development of forests; the use of solar energy, the earth's internal heat, and the earth's rotational energy; the disintegration of elements; and the underground gasification of coal. ${ }^{5} \mathrm{~A}$ member of this committee, the famous English chemist Sir William Ramsey, became very interested in underground gasification, and even decided to pursue Betts' method using a single borehole. In 1912, Ramsey lectured at the opening of an International Smoke Abatement Exhibition in London in which he elucidated some of the virtues of in situ coal gasification: clean air, reduced transportation costs, independence from the coal miners' unions (England was in the midst of a coal miner's strike), and the use of gas turbines instead of steam turbines, which he believed to be twice as energy efficient. 9 Ramsey also described his gasification experiment in some detail. A boring would be "put down to the coal; through conair and steam, and thus make water gas where the coal was located, instead of raising it to the surface, to make the same gas. A tube 6 in. in diameter would probably suffice, and, as it descended, it would reveal the exact nature of the various strata. You would have no expensive shaft to sink, tunnels to drive, rubbish to remove. The boring could probably be done for from $£ 1000$ to $£ 5000$. Inside this tube, you could insert two smaller pipes, one inside the other, the smaller of the two for the purpose of pumping out the water, and the other for passing down air, steam or small quantities of water to burn with the coal - there is nothing new in that. The coal of course, would easily be ignited, in the first instance, by passing down an electric wire, which would then be withdrawn."

The International Smoke Abatement Exhibition was designed to draw support from the public in fighting air pollution. Ramsey's remarks thus were widely circulated in the popular press. Lenin, living in exile in western Europe during this period, read reports of Ramsey's speech and was intrigued by the humanitarian and social aspects of underground gasification. He was impressed by both the inexpensive power and the improved working conditions that might result from freeing the miners from the strenuous, backbreaking underground labor. On May 4, 1913, in Pravda, Lenin published a glowing account of Ramsey's technique entitled "One of the Great Triumphs of Technology."10 
"At present," he wrote, "in order to use the energy contained in coal, it is transported about the country and burned in a large number of individual enterprises at home. Ramsey's discovery [sic] means a gigantic technical revolution in a branch of production of the capitalist countries which may be most important. Ramsey discovered a method of direct conversion of this coal into gas on the spot, that is, at the point where the coal was found without extracting it to the surface of the earth.

"Ramsey's method converts coal mines, as it were, into gigantic distillation apparatuses for the production of gas. Gas motors, in turn, convert the energy into electricity, which technology can already transport over enormous distances.

"The cost of electric current would be reduced, employing this technical revolution, to one-fifth (of the present cost) and maybe even to one-tenth of today's present cost. The enormous mass of human labor expended now on extracting and transporting coal would be saved. The industrial revolution caused by this discovery will be enormous: But, the consequences of this revolution for all the social life of the present capitalist society will not amount to what this discovery will mean for socialism.

\footnotetext{
"In the case of capitalism the 'Iiberation' of millions of miners
}

occupied with the extraction of coal will certainly lead to mass unemployment, and enormous increase in poverty, a worsening of the situation of the workers. And the gain from this great discovery will 1ine the pockets of the Morgans, the Rockefellers, the Ryabushinskis, the Morozov, and their train of lawyers, directors, professors and other lackeys of capitalism."10

A11 the Soviet sources refer to "Ramsey's system of underground gasification of coa1."11 In fact, an article with that title appeared in Mir otkmytiy (World of Discoveries) 1912. 11 In 1934, Podzemnaya Gazifikatsiya Ugley (Underground Gasification of Coal) ${ }^{12}$ carried a lengthy description and diagrams of "Ramsey's system" (Fig. 2). However, after considerable research in scientific Iiterature $1,13,14$ failed to reveal any publications by Ramsey, we can only conclude that while Ramsey was instrumental in initiating experimental work and in publicizing in situ coal gasification, he did not originate the scheme that he intended to try. Ramsey did manage to obtain funding and began preparations for a small underground gasification experiment, but he died before accomplishing anything of consequence. Because of his untimely death and the outbreak of World War I, all experiments in underground coal gasification in England were terminated and were not resumed until after World War II. 


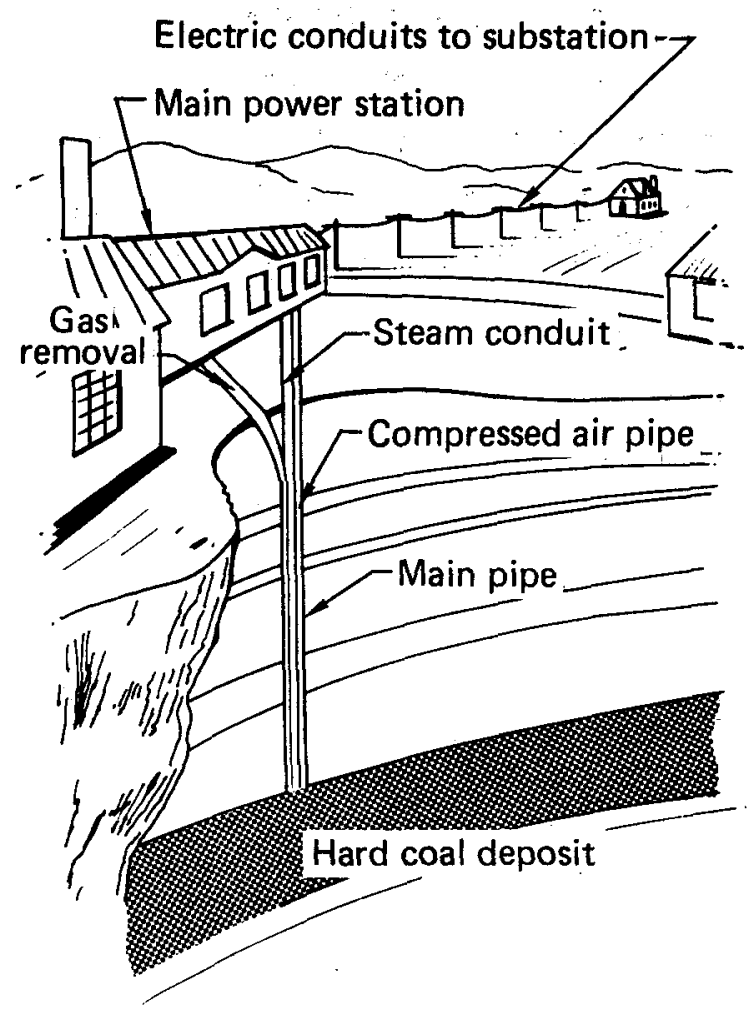

Fig. 2. Scheme of Ramsey's proposal.

It is perhaps not surprising that Betts' patent was forgotten in the wake of a person such as Sir William Ramsey. Consider the following, abstracted from Nature in 1916: In eulogizing Ramsey in $1916,{ }^{15} \mathrm{~S}$ ir Hugh Bell, Bart., the person responsible for funding Ramsey's underground gasification experiment, "referred to a suggestion made to him by Ramsey some time ago as to the possibility of distilling small seams of coal in situ. Probably no person other than Ramsey would have been able to persuade him that the experiment was at all possible, but, like others, he fell under the glamour of an entranc- ing personality, and arrangements were made for trying the experiment."

A1though there is some indication that Lenin included underground coal gasification as a part of the Soviet research program during World War $I, 16$ it probably did not receive any further consideration until 1920, when a mining engineer, V. I. Belov, suggested in situ gasification of the thin, unworked coal seams in the Donets Basin. In 1925, Professor B. I. Bokiy of the Leningrad Mining Institute suggested that the electrification of Russia might be made possible by underground coal gasification. He pointed out that Mendeleyev's project "is no Utopia and can be worked out on a fully scientific basis. "11 Bokiy presented a brief technical description of a method for gasifying coal in a block. ${ }^{7}$ However, the Soviet Union was busy with post-war reconstruction and nothing was actually done with Bokiy's suggestions, although his article was useful in maintaining an interest in underground coal gasification. About 1928, I. P. Kirichenko started actively planning the first Soviet underground coal gasification experiments. ${ }^{12} \mathrm{He}$ published an article in Ggo $^{17}$ (Coa1) in 1930, describing in technical detail his proposed method for in situ coal gasification. The work of implementing this method began at Lisichansk in $1932 .^{18}$ 
In 1930 , the men and officers from a cavalry regiment of the Workers' and Peasants' Red Army wrote a letter that was published in Novaya Tekhnika (New Technology) appealing to "al1 scientists of our country, all scientific-research institutes, the whole proletarian student body of chemical and mining institutes directed by Soyuzugol', the VSNKh [Higher Soviets of the National Economy] of the USSR and the Ukraine, al1 members of VARNITSO [Al1-Union Association of Scientific and Technical Workers for the Creation of a Socialist Society] and the Committee for the Chemicalization of the National Economy." 7 A similar letter was also directed to the Central Committee of the All Union Communist Party. Previously, a group of scientists from the Moscow Mining Institute had addressed the Central Committee urging them to organize experiments in underground gasification ${ }^{12}$ and in 1931, a resolution was passed by the Central Committee to begin the first experiments. Following Stalin's suggestion, the Commission for the Underground Gasification of Coal was formed to organize the research. In 1933 a. special state trust called "Podzem" (underground) was established as the experimental branch of the commission. ${ }^{12}$ Its purpose was to develop the investigations more thoroughly.

\section{Chamber Method}

With state funding, several underground coal gasification projects began in 1933. Kirichenko's scheme, pub1ished in UgoZ in 1930, simply employed surface gasification methods underground in the coal seam. It formed the basis for all the early experiments in the western part of the Soviet Union. (Kirichenko recieved. a Russian patent on this process in 1930. Russian Patent \#28,274, Nov. 21, 1930.) According to this scheme, four intersecting channels were mined out in the seam. In some cases the channels were rein- forced with timber, as, for example, at Lisichansk, where the bedding was unstable (Fig. 3). The coal panel* thus marked for gasification was then surrounded by a thick barrier usually composed of at least two brick or rock walls separated by tamped clay; in other words, a furnace or chamber was built underground. This was called the chamber method of underground coal gasification. Precisely, as in surfar coal gasification, the

\footnotetext{
* Panel is the conventional Soviet te $\mathrm{m}$ for the portion of the seam to be gasified.
} 


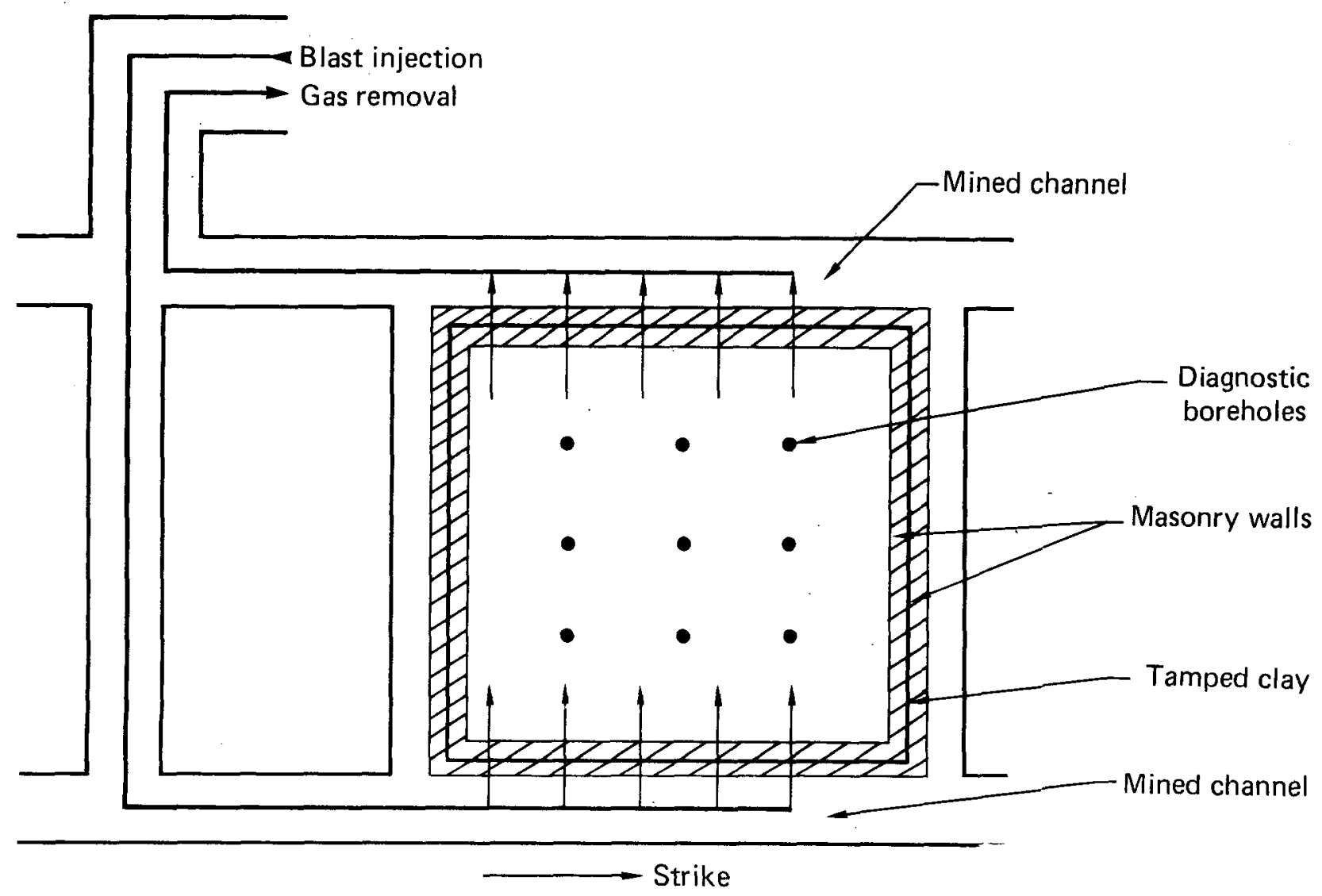

Fig. 3. Diagram of Kirichenko's chamber method (plan view).

masonry walls were to contain the fire and prevent it from spreading through the coal seam, as well as to provide a leak-tight chamber for the reaction. (As Mendeleyev had been, these early mining engineers were very mindful of uncontrolled fires that frequently swept the mines.)

In general, the coal within the furnace was crushed either before or during gasification. (An early abortive attempt using Moscow Basin brown coal in a solid pillar and relying on the natural fissures to provide sufficient surface area, showed that if the chamber method were used, coal must first be crushed.) Along one side of the coal panel inside the furnace, space was left for an ignition channel. Kerosene-soaked wood or rags were placed in the channel. often, crushed coal was also used to increase the heat of the fire. The panel was ignited just before it was sealed and the blast entered the reaction chamber through pipes that were sealed in the middle of the wall on one side of the chamber. The product gas exited through a corresponding set of pipes in the middle of the opposite wall. For dipping seams like most of those in the Donets 
Basin, if the blast entered through the bottom of the gasification panel, and, if the coal burned from the lower drift upward along the dip, the process was clearly analogous to that of surface gasifiers. The blast was supplied by simple blowers either on the surface or in one of the mined-out channels in the seam near the gasification site. To increase efficiency, an exhaust fan supplied reduced pressure to the output side. The input blast and output product gas were usually carried through the mined-out channels in heavy steel pipes.

The Soviets were very careful to employ every available means to observe and monitor the process. An array of boreholes was drilled from the surface into the coal panel for gas sample extraction, thermocouples, and, in some cases for acoustic sensors. In some experiments that employed the chamber method of gasification, windows were placed in the walls of the furnace so that the process could be watched, at least until temperatures became excessive. In 1935, Kirichenko, speaking of the Lisichansk experiments, wrote in Gomyi Zhumal (Mining Journal) that, "We must say that one of the most difficult tasks involved in the underground gasification process is to conduct the measurements and observations of the process, which takes place deep underground, and the solu- tion of this problem will require a great deal of work." 18

Although the first shaft for the underground gasification of coal began at Lisichansk in the Donets Basin in April 1932, ${ }^{18}$ the first underground gasification of coal actually occurred in the Moscow Basin at Krutova in the spring of 1933. Prior to the underground field test at Krutova, no experimental work on underground coal gasification had been conducted in the Moscow Basin. For this experiment in a horizontal seam, the surface gasifier design was turned on its side (Fig. 4). The chief aims of the first experiment were simplicity and minimum cost. (See Table 1 for seams, coal, and product gas characteristics.) The coal panel to be gasified was not even broken up before the fire was started because it was hoped that the natural fissures would supply enough surface area to sustain the reaction. In the preliminary tests before ignition, it was found that the reaction chamber was not 1eak-proof. At pressures over $0.01 \mathrm{~atm}$, there were large losses into the overburden and around the walls surrounding the coal pane1. Although attempts to reduce the leaks failed, it was decided to gasify. The gas collected from the offtake pipes and from the diagnostic boreholes contained only about $5 \% \mathrm{CO}$ and generally as much as $10-14 \% 0_{2}$ 


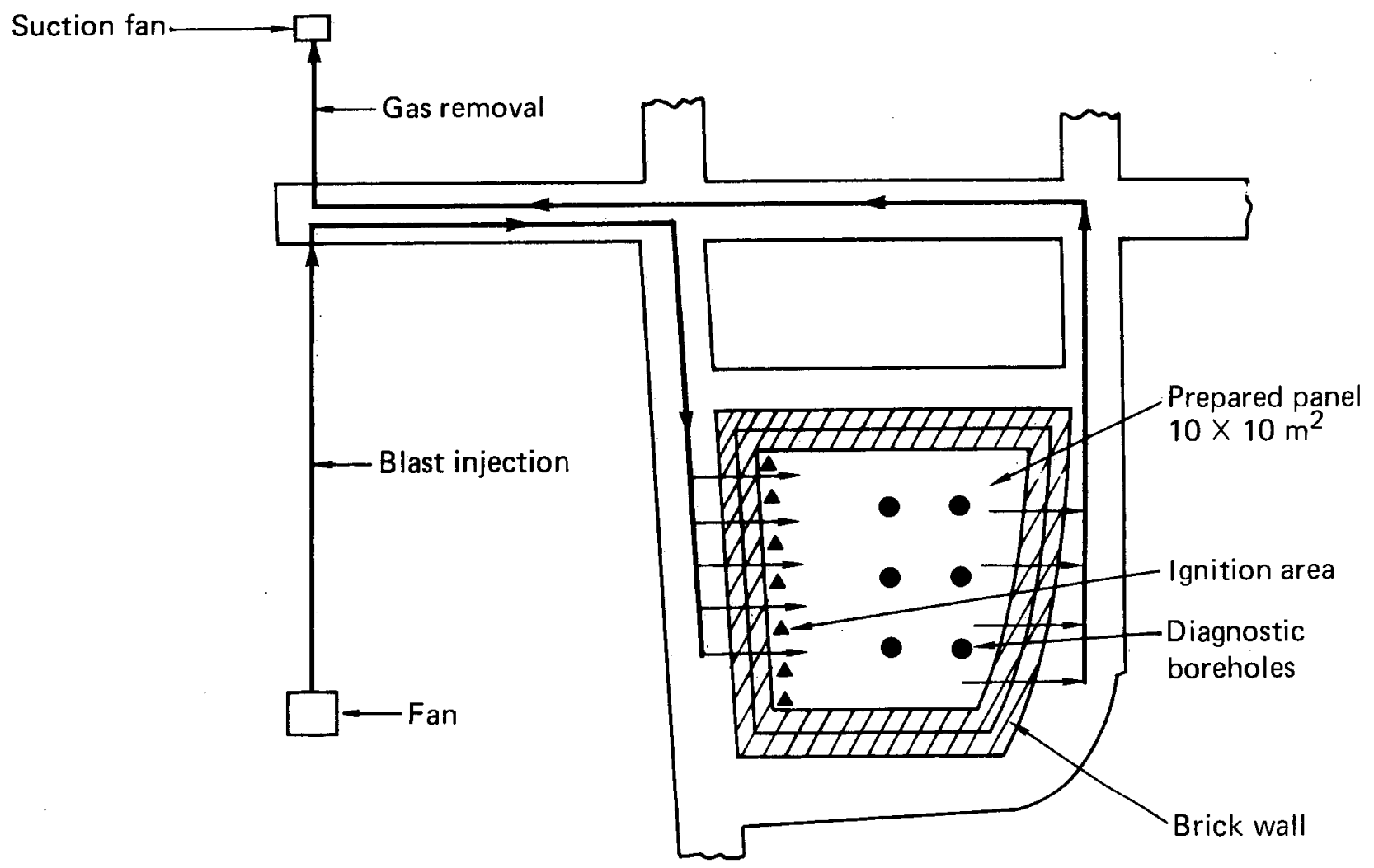

Fig. 4. Krutova experimental panel (plan view).

(Appendix A). The coal burned at an extremely slow rate. Because changing the blast intensity (flow rate) did not seem to alter the process in any observable way, it was decided to drill several holes from the surface into the coal seam, drop in explosives to break up the coal, and continue the experiment using fractured coal as Kirichenko had originally suggested. The product gas was substantially better after the coal was crushed than it had been from the unfractured block; gas with $12 \% \mathrm{CO}$ and a heating value of $989 \mathrm{kcal} / \mathrm{m}^{3}$ was obtained from the diagnostic boreholes. (The heating value given in these early experiments is the lower heating value (Ref. 19). Gas compositions are given on a water-free basis.) Note that to obtain gas with an appreciable amount of $\mathrm{CO}$, it was necessary to remove the product gas from a diagnostic borehole located in an area near a combustion center, instead of from the offtake pipe. The process was still extremely slow. When the panel was reopened after the experiment was concluded, only about $5 \%$ (10 tonnes) of the coal had been burned.

At Krutova, the capacity of each injection fan was on $1 \mathrm{y} 6000 \mathrm{~m}^{3} / \mathrm{hr}$, under overpressures of 0.06 atm or 
Table 1. Gasification data and coal characteristics for the early Soviet underground gasification experiments.

\begin{tabular}{|c|c|c|c|c|c|c|c|}
\hline $\begin{array}{l}\text { Place of } \\
\text { Trial }\end{array}$ & Trial time & Method used & Panel size & $\begin{array}{l}\text { Gas char- } \\
\text { acteristics }\end{array}$ & Remarks & $\begin{array}{l}\text { Seam char- } \\
\text { acteristics }\end{array}$ & $\begin{array}{l}\text { Coal char- } \\
\text { acteristics }\end{array}$ \\
\hline Krutova & Mar. 10-17, 1.933 & $\begin{array}{l}\text { Chamber method, } \\
\text { broken by dyna- } \\
\text { mite before gas- } \\
\text { ification }\end{array}$ & $\begin{array}{l}10 \times 10 \mathrm{~m} \\
200 \mathrm{t}\end{array}$ & $\begin{array}{l}10-1.2 \% \mathrm{CO} \\
10-14 \% \mathrm{O}_{2} \\
5-6 \% \mathrm{H}_{2} \\
3-4 \% \mathrm{CH}_{4} \\
989 \mathrm{kca} 1 / \mathrm{m}_{3} \\
\text { obtained from. } \\
\text { boreholes. }\end{array}$ & $\begin{array}{l}\text { Airblast } \\
1.500 \mathrm{~m}^{3} / \mathrm{h} \\
\text { Moscow Min- } \\
\text { ing Inst. } \\
\text { plan of V.P. } \\
\text { Federov. } \\
\text { Only } 5 \% \text { of: } \\
\text { available } \\
\text { coal was } \\
\text { burned. }\end{array}$ & $\begin{array}{l}20 \mathrm{~m} \text { deep, } \\
\text { flat seam, } \\
1.75 \mathrm{~m} \text { thick; } \\
\text { unstable roof of } \\
\text { sand and clay, } \\
\text { little water } \\
\text { intrusion. }\end{array}$ & $\begin{array}{l}\text { Brown coal (Lig- } \\
\text { nite), low grade: } \\
30-34 \% \mathrm{H}_{2} \mathrm{O} \\
40-50 \% \text { ash very } \\
\text { friable } 36-45 \% \text {, } \\
\text { volatiles. density } \\
1.28 \mathrm{t} / \mathrm{m}^{3} \text { (very } \\
\text { porous); incom- } \\
\text { bustible even when } \\
\text { dry, ignites at } \\
140-150^{\circ} \text { in oxygen- } \\
\text { enriched air. }\end{array}$ \\
\hline Shakhty & $\begin{array}{l}\text { Nov. \& Dec. } 1933 \\
\therefore \\
\text { Jan. } 1934\end{array}$ & $\begin{array}{l}\text { Chamber method } \\
\text { broken by dynat- } \\
\text { mite before gas- } \\
\text { ification; } \\
\text { Chamber method, } \\
\text { coal removed, } \\
\text { broken by hand } \\
\text { \& replaced } \\
\text { (storing) }\end{array}$ & $\begin{array}{l}1.0 \times 35 \mathrm{~m}^{*} \\
.10 \times 35 \mathrm{~m}^{*}\end{array}$ & $\begin{array}{l}\text { Gasification } \\
\text { did not pro- } \\
\text { ceed. } \\
7.7-13 \% \text { Co } \\
1.3-27 \% \mathrm{H}_{2} \\
0.2-2 \% \mathrm{CH}_{4} \\
600-1.250 \\
\text { kca } 1 . / \mathrm{m}^{3} \text { ob- } \\
\text { tained from } \\
\text { boreholes. }\end{array}$ & $\begin{array}{l}\text { A.S. Kuznetsov. } \\
\text { Air blast } \\
7000 \mathrm{~m}^{3} / \mathrm{h} \\
\text { run in cycli- } \\
\text { cal fiashion; } \\
\text { a.ir blast } \\
2-4 \mathrm{hr} \text {, off } \\
1.5 \mathrm{~min} \text {; ex- } \\
\text { haust fan on } \\
\text { for a short } \\
\text { period. }\end{array}$ & $\begin{array}{l}\text { Depth unknown } \\
1.9-22 \% \text { dip, } \\
0.38 \mathrm{~m} \text { thick, } \\
\text { roof: clayey } \\
\text { shale plus } \\
\text { bands of: sand } \\
\text { and clay; } \\
\text { floor:sandy } \\
\text { shale: } 1.00 \mathrm{~s} \text { \& } \\
\text { roof: } 6-7 \% \mathrm{H}_{2} \mathrm{O}, \\
\text { roof rocks: } \\
\text { stable. }\end{array}$ & $\begin{array}{l}\text { Anthracite: } \\
3.5 \% \mathrm{H}_{2} \mathrm{O} \\
4.4 \% \text { ash } \\
94.3 \% \text { fixed carbon } \\
2.5 \% \text { volitiles. }\end{array}$ \\
\hline Lisichansk & $\begin{array}{lll}\text { Feb. } & 16, & \text { to } \\
\text { Ju1. } & 29, & 1934\end{array}$ & $\begin{array}{l}\text { Chamber method, } \\
\text { dynamited dur- } \\
\text { ing gasifica- } \\
\text { tion }\end{array}$ & $\begin{array}{l}65 \times 45 \mathrm{~m}^{*} \\
1600 \mathrm{t}\end{array}$ & $\begin{array}{l}6-12 \% \mathrm{CO} \\
7.8-20.6 \% \mathrm{H}_{2} \\
2.8-4.2 \% \mathrm{CH}_{4} \\
0.6-0.9 \% \mathrm{OC}^{2} \\
12-18 \% \mathrm{Co}^{2} \\
753-1054 \\
\mathrm{kcal} / \mathrm{m}^{3} \text { ob- } \\
\text { tained from } \\
\text { boreholes. }\end{array}$ & $\begin{array}{l}\text { I.P. Kirichenko. } \\
\text { Air blast } \\
\text { Brief incon- } \\
\text { clusive test } \\
\text { with } 47 \% \mathrm{O}_{2} \\
\text { enrichment. }\end{array}$ & $\begin{array}{l}24-30 \mathrm{~m} \text { deep } \\
36^{\circ}-45^{\circ} \text { dip, } \\
0.75 \mathrm{~m} \text { thick } \\
\text { shale floor } \\
\text { and roof. }\end{array}$ & $\begin{array}{l}\text { Bituminous, long- } \\
\text { flame coal: } \\
10-14 \% \mathrm{H}_{2} \mathrm{O} \\
12-21 \% \text { ash } \\
36 \% \text { volatiles } \\
54 \% \text { fixed carbon. }\end{array}$ \\
\hline
\end{tabular}


Table 1. (cont.)

\begin{tabular}{|c|c|c|c|c|c|c|c|}
\hline $\begin{array}{l}\text { Place of } \\
\text { Trial }\end{array}$ & Trial time & Method used & Panel size & $\begin{array}{l}\text { Gas char- } \\
\text { acteristics }\end{array}$ & Remarks & $\begin{array}{l}\text { Seam char- } \\
\text { acteristics }\end{array}$ & $\begin{array}{l}\text { Coal char- } \\
\text { acteristics }\end{array}$ \\
\hline & Apr. 24, 1934 & $\begin{array}{l}\text { Single vertical } \\
\text { hole as de- } \\
\text { scribed by } \\
\text { Ramsey }\end{array}$ & $\begin{array}{l}\text { Hole diam- } \\
\text { eter un- } \\
\text { known }\end{array}$ & $\begin{array}{l}55 \% \mathrm{CO} \\
24 \% \mathrm{H}_{2} \\
0.3 \% \mathrm{CH}_{4} \\
0.6 \% \mathrm{O}_{2} \\
13 \% \mathrm{CO}_{2} \\
2500 \mathrm{kcal} / \mathrm{m}^{3}\end{array}$ & $\begin{array}{l}\text { Blast was } \\
\text { pure oxygen } \\
\text { at } 7 \text { atms; } \\
\text { experiment } \\
\text { terminated } \\
\text { after } 4 \text { hr be- } \\
\text { cause pipe } \\
\text { melted. }\end{array}$ & & ' \\
\hline $\begin{array}{l}\text { Leninsk- } \\
\text { Kuznets }\end{array}$ & $\begin{array}{l}\text { Jun. } 4, \text { to } \\
\text { Nov. } 17,1934\end{array}$ & Stream method. & $\begin{array}{l}6.5 \text { to } 9 \mathrm{~m} \\
\times 20 \mathrm{~m}^{*} \\
1000-1500 \mathrm{t}\end{array}$ & $\begin{array}{l}6 \% \mathrm{CO} \\
20 \% \mathrm{H}_{2} \\
15 \% \mathrm{CH}_{4} \\
1.75 \% \mathrm{O}_{2} \\
13 \% \mathrm{Co}^{2} \\
2400 \mathrm{kcal} / \mathrm{m}^{3} \\
\text { obtained from } \\
\text { off-take pipe. }\end{array}$ & $\begin{array}{l}\text { B.F. Grindler } \\
\text { air blast } \\
150-200 \mathrm{~m}^{3} / \mathrm{h} \text {. }\end{array}$ & $\begin{array}{l}28-30 \mathrm{~m} \text { deep } \\
20^{\circ} \text { dip, } 4.85 \mathrm{~m} \\
\text { thick. }\end{array}$ & $\begin{array}{l}\text { Bituminous, } \\
\text { high-grade } \\
\text { coking coal: } \\
9.7 \% \mathrm{H}_{2} \mathrm{O} \text {. } \\
3.5 \% \text { ash, } \\
44.6 \% \text { vola- } \\
\text { tiles, } 58 \% \\
\text { fixed carbon }\end{array}$ \\
\hline \multirow[t]{3}{*}{ Lisichansk } & Jul. 2, 1934 & $\begin{array}{l}\text { Single borehole } \\
\text { No. } 1\end{array}$ & $\begin{array}{l}8 \mathrm{~m} \text { long, } \\
\text { initial diam- } \\
\text { eter } 60 \mathrm{~mm}\end{array}$ & $\begin{array}{l}\text { Almost no pro- } \\
\text { duct gas ob- } \\
\text { tained due } \\
\text { to leaks. }\end{array}$ & $\begin{array}{l}\text { Borehole lay } \\
\text { at an angle } \\
\text { of } 45^{\circ} \text { to the } \\
\text { strike. }\end{array}$ & \multicolumn{2}{|c|}{$\begin{array}{c}\text { Same as previous Lisichansk } \\
\text { experiment. }\end{array}$} \\
\hline & Jul. 22, 1934 & $\begin{array}{l}\text { Single borehole } \\
\text { No. } 2\end{array}$ & $\begin{array}{l}17.5 \mathrm{~m} \text { long, } \\
\text { initial diam- } \\
\text { eter. } 100 \mathrm{~mm}\end{array}$ & $\begin{array}{l}11.2-11.9 \% \mathrm{CO} \\
10.2-13.8 \% \mathrm{H}_{2} \\
0.6-2.3 \% \mathrm{CH}_{4} \\
0.4-1.8 \% \mathrm{O}_{2} \\
10.5-11.9 \% \\
\mathrm{CO}_{2}, 800-880 \\
\mathrm{kca} 1 / \mathrm{m}^{3} .\end{array}$ & $\begin{array}{l}\text { Gas leaks forced } \\
\text { terminations of } \\
\text { experiment after } \\
8 \mathrm{hr} \text {. }\end{array}$ & & \\
\hline & Ju1. 27, 1934 & $\begin{array}{l}\text { Single borehole } \\
\text { No. } 2\end{array}$ & $\begin{array}{l}17.5 \text { m long, } \\
\text { initial diam- } \\
\text { eter un- } \\
\text { known }\end{array}$ & $\begin{array}{l}10.0-15.6 \% \mathrm{CO} \\
12.3-15.9 \% \mathrm{H}_{2} \\
0.3-2.6 \% \mathrm{CH}^{4} \\
0.05-0.3 \% 0_{2}^{4} \\
9.1-14.6 \% \mathrm{CO}_{2} \\
800-1000 \\
\mathrm{kca} 1 / \mathrm{m}_{3} .\end{array}$ & $\begin{array}{l}\text { Various proce- } \\
\text { dures were under- } \\
\text { taken to eliminate } \\
\text { leaks and the fire } \\
\text { was restarted in } \\
\text { borehole No. } 2 \text {. }\end{array}$ & & \\
\hline
\end{tabular}


Table 1. (cont.)

\begin{tabular}{|c|c|c|c|c|c|c|c|}
\hline $\begin{array}{l}\text { Place of } \\
\text { Trial }\end{array}$ & Trial time & Method used & Panel size & $\begin{array}{l}\text { Gas char- } \\
\text { acteristics }\end{array}$ & Remarks & $\begin{array}{l}\text { Seam char- } \\
\text { acteristics }\end{array}$ & $\begin{array}{l}\text { Coal char- } \\
\text { acteristies }\end{array}$ \\
\hline Krutova & $\begin{array}{lll}\text { Aug. } 13 \text { to } \\
\text { Dec. } 1, & 1934\end{array}$ & $\begin{array}{l}\text { Chamber method, } \\
\text { dynamited dur- } \\
\text { ing gasifica- } \\
\text { tion. }\end{array}$ & $\begin{array}{l}18 \times 40 \mathrm{~m} \\
1.000 \mathrm{t}\end{array}$ & $\begin{array}{l}0.4-7.6 \% \mathrm{CO} \\
0.6-20 \% \mathrm{H}_{2} \\
0.3-11 \% \mathrm{CH}_{4} \\
15-23 \% \mathrm{CO}_{2} \\
\text { occasional1y } \\
\text { obtained from } \\
\text { boreholes. }\end{array}$ & $\begin{array}{l}\text { In general, } \\
\text { gas from } \\
\text { boreholes was } \\
\text { poor, only } \\
0.1 \text { to } 1 \% \text { co. }\end{array}$ & $\begin{array}{l}1.5 \mathrm{~m} \text {-deep, flat } \\
\text { seam, } 2.5-\mathrm{m} \\
\text { thick; unstable } \\
\text { roof of sand } \\
\text { and clav. }\end{array}$ & $\begin{array}{l}\text { Generally sam } \\
\text { coal char- } \\
\text { aracteristics } \\
\text { as previous } \\
\text { Krutova ex- } \\
\text { periment. }\end{array}$ \\
\hline \multirow[t]{3}{*}{ Lisichansk } & sug. 26,1934 & $\begin{array}{l}\text { Single borehole } \\
\text { No. } 3 \text {. }\end{array}$ & $\begin{array}{l}1.3 \mathrm{~m} \text { long } \\
\text { Initia1. diam- } \\
\text { eter } 100 \mathrm{~mm}\end{array}$ & $\begin{array}{l}12.4-15.7 \% \mathrm{CO} \\
9.3-13.1 \% \mathrm{H}_{2} \\
1.1-3.2 \% \mathrm{CH}_{4} \\
0.0-0.7 \% \mathrm{O}_{2} \\
9.1-11.2 \% \mathrm{CO}_{2} \\
840-10.10 \\
\mathrm{kcal} / \mathrm{m}^{3} .\end{array}$ & $\begin{array}{l}\text { Because of } \\
\text { error in dril1- } \\
\text { ing one end } \\
\text { of hole was } \\
200 \mathrm{~mm} \text { above } \\
\text { seam filoor and } \\
\text { other } 200 \mathrm{~mm} \\
\text { below seam } \\
\text { floor; hole was } \\
1.9 \mathrm{~m} \text {, with } 13 \mathrm{~m} \\
\text { in coal and } 6 \mathrm{~m} \\
\text { in underburden. }\end{array}$ & \multirow{2}{*}{\multicolumn{2}{|c|}{$\begin{array}{l}\text { Same as previous Lisichansk } \\
\text { experiment. }\end{array}$}} \\
\hline & Sep. 5-8, 1934 & $\begin{array}{l}\text { Single borehole } \\
\text { No. } 3 .\end{array}$ & $\begin{array}{l}13 \text { m long } \\
\text { Initial diam- } \\
\text { eter un- } \\
\text { known }\end{array}$ & $\begin{array}{l}9-14 \% \mathrm{CO} \\
5-1.7 \% \mathrm{H}^{2} \\
0.7-3.4 \% \mathrm{CH}_{4} \\
0.1-0.6 \% \mathrm{O}_{2} \\
9-14 \% \mathrm{CO}_{2} \\
600-1100 \\
\mathrm{kcal} / \mathrm{m}^{3} .\end{array}$ & $\begin{array}{l}\text { Borehole number } \\
3 \text {, relit; experi- } \\
\text { ment terminated } \\
\text { after } 4 \text { days be- } \\
\text { cause of leaks; } \\
\text { gas quality de- } \\
\text { graded at end of } \\
\text { experiment be- } \\
\text { cause hole had } \\
\text { grown quite } \\
\text { large. }\end{array}$ & & \\
\hline & $\begin{array}{l}\text { Nov. } 26 \text { to } \\
\text { Dec. } 16,1934\end{array}$ & $\begin{array}{l}\text { Chamber method, } \\
\text { storing }\end{array}$ & $\begin{array}{l}288 \mathrm{~m}^{2} \\
216 \mathrm{~m}^{3} \\
177 \mathrm{t}^{\mathrm{t}} \\
20 \mathrm{~m}^{3} \text { air } \\
\text { above coal. }\end{array}$ & $\begin{array}{l}12-1.5 \% \mathrm{CO} \\
12-14 \% \mathrm{H}_{2} \\
1 .-3 \% \mathrm{CH}_{4} \\
1-2 \% \mathrm{O}_{2} \\
10-1.2 \% \mathrm{CO}_{2} \\
750-1080 \\
\mathrm{kcal} / \mathrm{m}^{3} \mathrm{ob}- \\
\text { tained from } \\
\text { boreholes. }\end{array}$ & $\begin{array}{l}\text { I.P. Kirichenko } \\
\text { gas quality } \\
\text { quickly de- } \\
\text { graded to a1- } \\
\text { most pure } \mathrm{CO}_{2} \\
\text { because of } \\
\text { oxygen by- } \\
\text { pass. }\end{array}$ & $\begin{array}{r}\text { Same as previous } \\
\text { experimen }\end{array}$ & $\begin{array}{l}\text { Lisichansk } \\
\text { ent. }\end{array}$ \\
\hline
\end{tabular}


Table 1. (cont.)

\begin{tabular}{|c|c|c|c|c|c|c|c|}
\hline $\begin{array}{l}\text { Place of } \\
\text { Trial }\end{array}$ & Trial time & Method used & Panel size & $\begin{array}{l}\text { Gas char- } \\
\text { acteristics }\end{array}$ & Remarks & $\begin{array}{l}\text { Seam char- } \\
\text { acteristics }\end{array}$ & $\begin{array}{l}\text { Coal char- } \\
\text { acteristics }\end{array}$ \\
\hline Krutova & Jan. 5-18, 1935 & $\begin{array}{l}\text { Series of bore- } \\
\text { holes }\end{array}$ & $\begin{array}{l}6 \text { holes } \\
\text { each } 12 \mathrm{~m} \text { long } \\
50 \mathrm{~mm} \text { diam- } \\
\text { eter, } 1 \mathrm{~m} \\
\text { apart; } 150 \mathrm{t} \\
\text { of coal pre- } \\
\text { pared. }\end{array}$ & $\begin{array}{l}1.9-5.5 \% \mathrm{CO} \\
6.1-15.5 \% \mathrm{H}_{2} \\
0.8-3.1 \% \mathrm{CH}_{4} \\
0.1-1 \% \mathrm{O}_{2} \\
19-41 \% \mathrm{CO}_{2} \\
420-720 \mathrm{kcal} / \\
\mathrm{m}^{3} \text { average } \\
570 \mathrm{kca} / \mathrm{m}^{3}\end{array}$ & $\begin{array}{l}\text { Relatively } \\
\text { stable opera- } \\
\text { tion; highest } \\
\text { heating value } \\
\text { gas obtained } \\
\text { when blast was } \\
\text { cut off. }\end{array}$ & $\begin{array}{l}21 \mathrm{~m} \text { deep flat } \\
\text { seam, } 2 \mathrm{~m} \\
\text { thick, un- } \\
\text { stable ronf of } \\
\text { sand \& clay. }\end{array}$ & $\begin{array}{l}25-30 \% \mathrm{H}_{2} \mathrm{O} \\
35 \% \text { ash; other } \\
\text { Krutova coal char- } \\
\text { acteristics } \\
\text { generally apply. }\end{array}$ \\
\hline Gorlovka & $\begin{array}{l}\text { Feb. 5, } 1935 \text { to } \\
\text { May 1, } 1936\end{array}$ & Stream method. & $\begin{array}{l}2 \text { pane } 1 \mathrm{~s} \text { each } \\
70 \times 25 \mathrm{~m} * \\
7000 \mathrm{t} \text { of } \\
\text { coal prepared }\end{array}$ & $\begin{array}{l}\text { With air: } \\
13-16 \% \mathrm{CO} \\
11-15 \% \mathrm{H}_{2} \\
2-5 \% \mathrm{CH}_{4} \\
0.2 \% \mathrm{O}_{2} \\
8-10 \% \mathrm{CO}_{2} \\
900-10 \mathrm{OOO}^{2} \\
\mathrm{kcal} / \mathrm{m}^{3}\end{array}$ & $\begin{array}{l}\text { Used steam } \\
\text { and oxygen to } \\
\text { increase } \\
\text { heating value } \\
\text { to } 1400 \mathrm{kcal} / \mathrm{m}^{3} \\
\text { used cyclical } \\
\text { operation to } \\
\text { obtain } \\
2400 \mathrm{kcal} / \mathrm{m}^{3} \\
20-30 \% \text { of the } \\
\text { time. }\end{array}$ & $\begin{array}{l}\text { 40-I10 m deep, } \\
70 \text { dip } \\
1.9 \text { m thick, } \\
\text { but barren bands; } \\
\text { only } 1.5 \mathrm{~m} \text { of coal; } \\
\text { roof was argilla- } \\
\text { ceous schist. } \\
\text { (Derezovka seam). }\end{array}$ & $\begin{array}{l}1 \% \mathrm{H}_{2} \mathrm{O} \\
30 \% \text { ash; } \\
18.5 \% \text { volatiles } \\
6000 \mathrm{kcal} / \mathrm{m}^{3} \\
\text { heating value. }\end{array}$ \\
\hline Lisichansk & Apr. $12-29,1935$ & $\begin{array}{l}\text { Series of bore- } \\
\text { holes }\end{array}$ & $\begin{array}{l}5 \text { holes } \\
1.5 \mathrm{~m} \text { apart } \\
12 \mathrm{~m} \text { long } \\
\text { each, } 200 \mathrm{t} .\end{array}$ & $\begin{array}{l}\text { With air } \\
\text { blast: } \\
9.4 \% \mathrm{CO} \\
12.8 \% \mathrm{H}_{2} \\
3 \% \mathrm{CH}_{4} \\
12 \% \mathrm{CO}_{2} \\
870-900 \\
\mathrm{kcal} / \mathrm{m}^{3} \\
\text { gradually gas } \\
\text { quality dete- } \\
\text { riorated. }\end{array}$ & $\begin{array}{l}\text { Approximately } \\
27 \% \text { of the } \\
\text { energy content } \\
\text { of the coal } \\
\text { burned was re- } \\
\text { covered in the } \\
\text { heating value of } \\
\text { the gas produced. }\end{array}$ & $\begin{array}{l}\text { Same as previou } \\
\text { experime }\end{array}$ & $\begin{array}{l}\text { us Lisichansk } \\
\text { ent. }\end{array}$ \\
\hline $\begin{array}{l}\text { Leninsk- } \\
\text { Kuznets }\end{array}$ & $\begin{array}{l}\text { Apr. } 27,1935 \text { to } \\
\text { Feb. } 25,1936\end{array}$ & Stream method & $\begin{array}{l}60 \times 50 \mathrm{~m} \cdot \\
18000 \mathrm{t} \\
\text { prepared }\end{array}$ & $\begin{array}{l}6.9 \% \mathrm{CO} \\
9.3 \% \mathrm{H}_{2} \\
4.4-6.0 \% \mathrm{CH}_{4} \\
0.6-1.4 \% \mathrm{O}_{2} \\
12.6-15.0 \% \mathrm{CO}_{2} \\
900-1100 \\
\mathrm{kcal} / \mathrm{m}^{3} .\end{array}$ & $\begin{array}{l}\text { Maximum avail- } \\
\text { able blast } \mathrm{fl} \text { low } \\
\text { rate }=400 \mathrm{~m}^{3} / \mathrm{h} . \\
\text { inadequate for } \\
\text { the large gas- } \\
\text { ification } \\
\text { channels used. }\end{array}$ & $\begin{array}{l}\text { Same as previous } \\
\text { Kuznets experim }\end{array}$ & $\begin{array}{l}\text { Leninsk- } \\
\text { ment. }\end{array}$ \\
\hline Krutova & May $18-31,1935$ & $\begin{array}{l}\text { Series of bore- } \\
\text { holes. }\end{array}$ & $\begin{array}{l}8 \times 7 \mathrm{~m}^{*}, 8 \\
\text { holes; was in } \\
\text { fact } 2 \text { pane } 1 \mathrm{~s} \\
4 \times 7 \mathrm{~m}^{*} \text {, each } \\
\text { of } 4 \text { holes. } \\
100-150 \mathrm{t}\end{array}$ & $\begin{array}{l}\text { No data } \\
\text { available. }\end{array}$ & $\begin{array}{l}\text { Only obtained } \\
\text { useful gas } \\
\text { part of the } \\
\text { time. }\end{array}$ & $\begin{array}{l}16-1 y \text { m deep } \\
\text { flat seam, } \\
2 \text { m thick. }\end{array}$ & \\
\hline
\end{tabular}


Tab1e 1. (cont.)

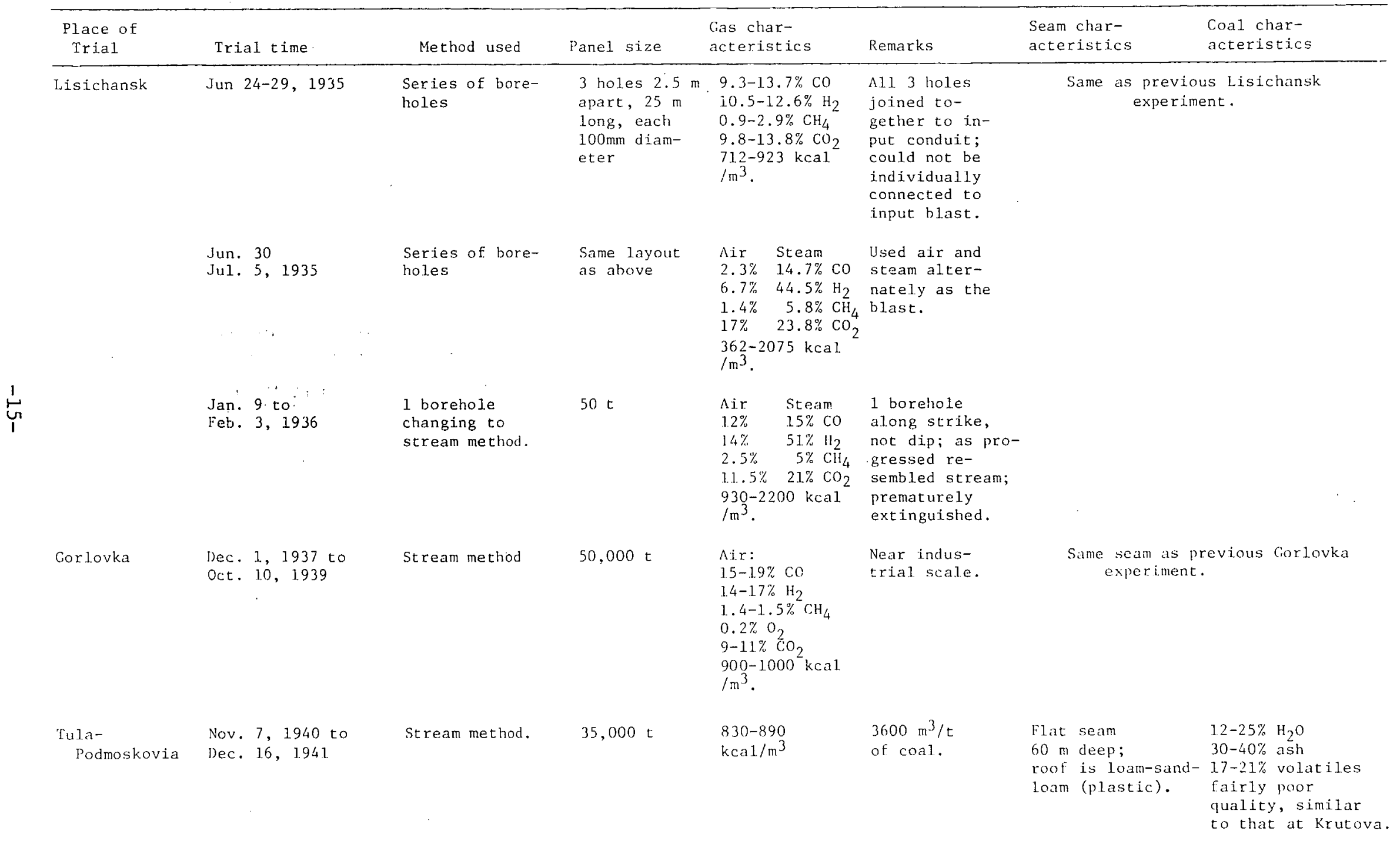


Table 1. (Cont.)

\begin{tabular}{|c|c|c|c|c|c|c|c|}
\hline $\begin{array}{l}\text { Place of } \\
\text { Trial }\end{array}$ & Trial time & Method used & Panel size & $\begin{array}{l}\text { Gas char- } \\
\text { acteristics }\end{array}$ & Remarks & $\begin{array}{l}\text { Seam char- } \\
\text { acteristics }\end{array}$ & $\begin{array}{l}\text { Coal char- } \\
\text { acteristics }\end{array}$ \\
\hline Lisichansk & $\begin{array}{l}\text { Dec. } 18,1940 \text { to } \\
\text { Nov. } 10,1941\end{array}$ & Stream method & $186,000 \mathrm{t}$ & $\begin{array}{l}900-1800 \\
\mathrm{kcal} / \mathrm{m}^{3}\end{array}$ & $\begin{array}{l}\text { Oxygen en- } \\
\text { riched; pro- } \\
\text { vided gas to } \\
\text { Don Soda } \\
\text { works. }\end{array}$ & $\begin{array}{l}138 \mathrm{~m} \text { greatest } \\
\text { depth, } \\
56^{\circ} \mathrm{dip}, \\
2.7 \mathrm{~m} \text { thick. }\end{array}$ & $\begin{array}{l}\text { Probably same as } \\
\text { previous Lisichansk } \\
\text { experiments; no exact } \\
\text { data available. }\end{array}$ \\
\hline Gorlovka & $\begin{array}{l}\text { Apr. } 25 \text { to } \\
\text { Oct. } 2,1941\end{array}$ & Stream method & $4000 t$ & $\begin{array}{l}850-950 \mathrm{kcal} \\
/ \mathrm{m}^{3}\end{array}$ & $\begin{array}{l}\text { Used for gas } \\
\text { turbine. }\end{array}$ & $\begin{array}{l}80 \mathrm{~m} \text { greatest } \\
\text { depth, } 70^{\circ} \mathrm{dip} \\
0.45 \mathrm{~m} \text { thick. }\end{array}$ & $\begin{array}{l}\text { Burakovka seam, no } \\
\text { data available. }\end{array}$ \\
\hline
\end{tabular}

\footnotetext{
*Measurement along dip given first.
} 
less on the blower and underpressures no greater than 0.005 to $0.006 \mathrm{~atm}$ on the exhuast fan. ${ }^{20}$ The actual intensity of the blast, was probably only about $1500 \mathrm{~m}^{3} / \mathrm{hr}$. (In 1960, Skafa stated the $5000 \mathrm{~m}^{3} / \mathrm{hr}$ is the "nearoptimum power" for the blast intensity in the underground gasification process. ${ }^{21}$ ) It was concluded that larger blowers should be used in future experiments. Several other conclusions were drawn from this first simple experiment. Horizontal coal seams could be gasified if the coal were first broken up. Reliable temperature measurement as well as accurate, prompt, and complete gas analyses were necessary if one expected to properly regulate the process of in situ gasification. Finally, the design for the insulating walls had to be changed to be able to build a leaktight chamber at minimum cost, "Or, methods of underground gasification must be worked out which will not require the use of insulating walls at all." 17

The second Russian gasification experiment was conducted in the Donets Basin at Shakhty on a slightly dipping ànthracite seam (Table 1). In this case, the coal was first broken up by explosives. Diagonal channels about 45 deg to the strike, were drilled from one side of the coal panel to the other. These were charged with dynamite and exploded electrically.
However, unbroken coal was always maintained next to the surrounding walls. It had been assumed that the natural fissures in the coal would widen upon heating, becoming large enough to sustain the burn and carry the gases to and from the combustion front. The cracks did not widen, and the process was also slowed down after a time because caved-in roof rock and slag formed a gas-impermeable layer between the blast injection point and the combustion center. Because of a lack of oxygen at the fireface, the fire eventually died. At this point, the panel was entered and a channel was opened the lower to the upper drift. (A drift is a channel mined along the strike of a seam.) The channel was filled with crushed anthracite and ignited near the lower drift. Thereafter, gasification was carried out in a cyclical fashion. Air was blown in for 2 to $4 \mathrm{hr}$, turned off for 10 to $15 \mathrm{~min}$, and then the exhaust fan was turned on and the accumulated product was removed. ${ }^{17}$ steam was not added to the blast at Shakhty because the water contained in the coal and the enclosing rocks provided more than sufficient steam (Appendix A). During the flowing period the quality of the gas was poor. While the blast and exhaust fan were turned off, the gas reached its maximum heating value $\left(1250 \mathrm{kcal} / \mathrm{m}^{3}\right)$. This was followed by 
a gradual decrease in the heating value to $600 \mathrm{kcal} / \mathrm{m}^{3}$ in the final phase when the exhaust fan was on. 14 Combustible gas could not be removed via the exhaust pipe in the upper drift, but rather, was removed through one of the diagnostic boreholes drilled into the coal panel. When the gas was allowed to leave through the exhaust pipe, it was completely oxidized by the input blast that channeled around the combustion zone.

At Shakhty, the amount of coal burned was nearly equal to the original charge in the chamber. Gasification of the walls helped compensate for the losses that resulted from the residues that were not burned. This second experiment still suffered from a leaky reaction chamber and lowintensity combustion, two problems that plagued the first experiment. Because more $\mathrm{CO}$ is formed at the expense of $\mathrm{CO}_{2}$ in a hotter reaction, it was felt that increasing the combustion intensity would have improved the gas quality. (Heat losses by conduction appeared to be insignificant.)

The blowing and exhaust equipment consisted of two blowers, each with a capacity of $3000 \mathrm{~m}^{3} / \mathrm{hr}$, at an overpressure of $0.007 \mathrm{~atm}$. These could be used in a series to obtain $0.013 \mathrm{~atm}$. There was an additional blower capable of, supplying $7000 \mathrm{~m}^{3} / \mathrm{hr}$ under 0.07 atm of pressure, and two exhausters with a capacity of
$4000 \mathrm{~m}^{3} / \mathrm{hr}$ and $3000 \mathrm{~m}^{3} / \mathrm{hr}$ each, at 0.02 and 0.01 atm respectively. This equipment, as well as the monitoring apparatus, proved very satisfactory. Coal block temperatures, blast and product gas pressure, volume, and content could all be measured and analyzed completely.

This experiment showed that the chamber method of in situ gasification required that the coal be broken up, but a suitable technique had not yet been found. In some boreholes the explosion was premature. In this case, the dynamite was detonated before the adjacent area was fractured; therefore, the coal had no void in which to explode, and rather than breaking up the coal, the explosion produced only small openings filled with dust and fine powder. In other cases, the large coal blocks settled into preexisting fissures, forming a channel at the top of the seam. This allowed the blast to pass between the surface of the coal and the roof, along the top of the coal 1ayer. ${ }^{17}$

Even when the detonations were properly sequenced, because of the relatively small angle of the dip and the thin seam, much of the detached coal remained in the same spot; i.e., the explosion produced no new reaction surfaces. It was becoming more evident that "new systems must be created differing in principle from those used at present."17 
However, not a11 Soviet underground coal gasification engineers shared this view. In 1935, Sazonov stated that, "The production of gas in a crushed panel approximating the process in an ordinary Siemens gasifier is considered as adapted to industrial experiments at present." 12 At least two more experiments were conducted at Shakhty using this method; see Table 1 for production data.

Although the experiment at Lisichansk was the third to actually gasify coal, underground mining preparations for this trial had begun at least 4 yr earlier. This was the most extensive effort thus far (Fig. 5).
A panel $45 \mathrm{~m}$ in strike by $65 \mathrm{~m}$ along the dip (1600 tons of coal) was enclosed. Both surface and underground preparations were very elaborate at Lisichansk. For example, the upper drift that was to carry the hot product gas was not only reinforced with timbers, it was actually lined with a cylinder of firebrick. There was an elaborate tar collecting system with pipes emptying into tank cars that could be raised to the surface. The isolating walls were $6 \mathrm{~m}$ thick along the ends and $10 \mathrm{~m}$ thick along the sides. Even before the gasification tests were completed and the product gas analyzed, it became obvious that the brick-lined off-take

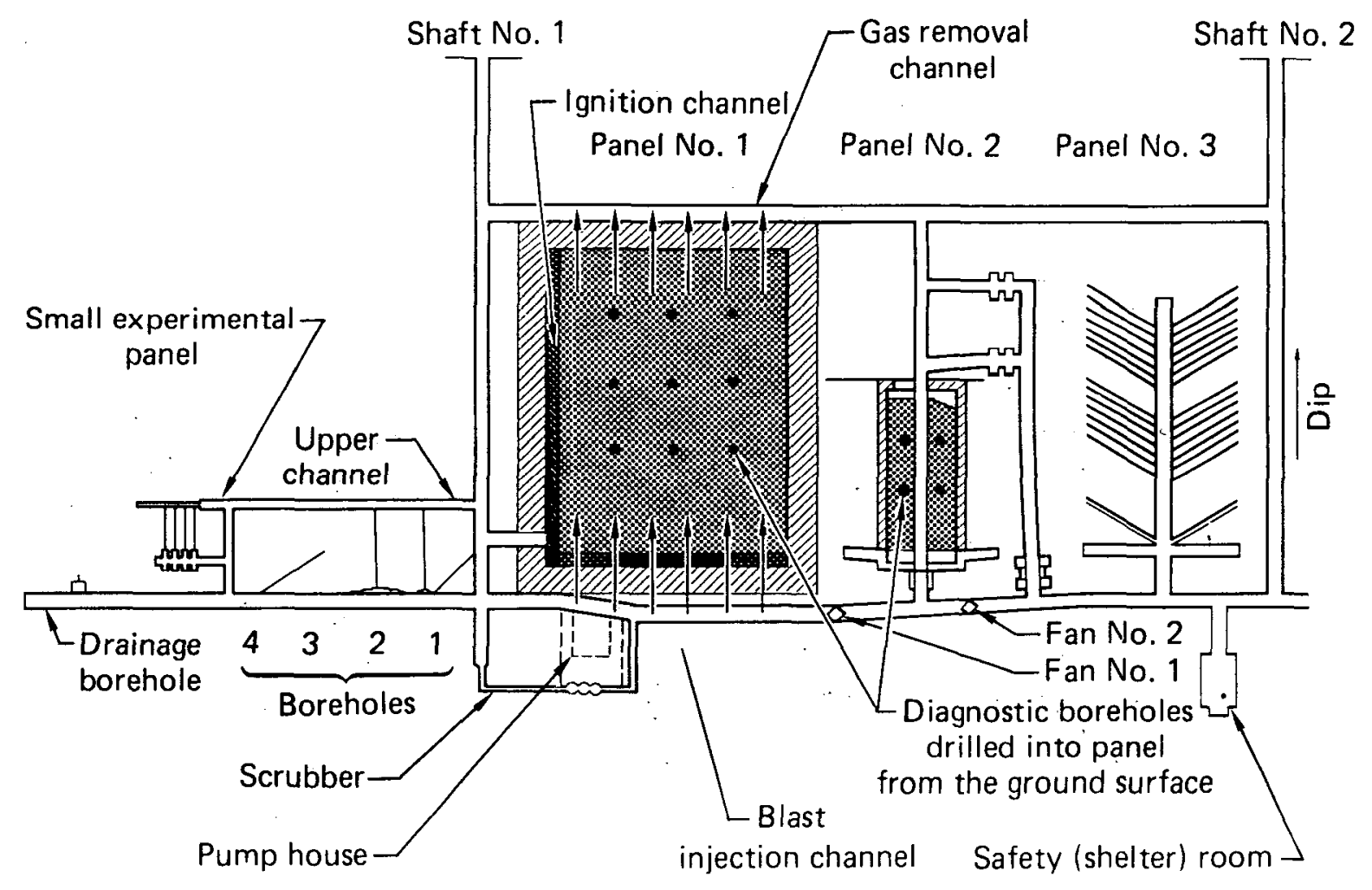

Fig. 5. Plan view of Lisichansk experimental area. 
pipe and the isolating walls were excessively complicated and expensive. It was decided that simple iron pipes should be adequate, and naturally occurring coal left in pillars along the panel perimeter would provide a more leak-tight reaction chamber. On the surface, in addition to the usual compressors and blowers, there were boilers to provide steam for the gasification, scrubbers to rid the product gas of tar and water, and even provision for using a part of the product gas to fire the boilers. The diagnostic and analyses facility was more complete than any used previosly.

For this third experiment the coal was broken up with explosives during gasification. In the preparatory phase, holes were drilled diagonally through the coal panel and explosive charges emplaced. (Kirichenko believed that one of the more significant remaining problems was accurate and efficient drilling of directed holes.) ${ }^{18}$ As gasification progressed, the heat of combustion exploded the charges. A special ignition channel lay beside the panel, along the dip. (In the first two experiments, the coal panel was ignited along a line running perpendicular to the direction of motion of the blast; i.e., the flame front would be expected to move in the direction of the blast. In the trial at Lisichansk, the coal panel was ignited along a line running parallel to the direction of motion of the blast (Fig. 5).) Nearly half its length was filled with crushed coal, the remainder with kerosenesoaked wood. Approximately $33 \mathrm{hr}$ after ignition the charges started exploding. Although the charges continued to explode and the coal seemed to be burning as expected, all the samples obtained from the offtake pipe contained approximately $19 \% \mathrm{CO}_{2}$, a figure representing almost complete combustion. Because it was believed that a broader combustion front would produce a hotter fire, (more $\mathrm{CO}$ and less $\left.\mathrm{CO}_{2}\right)$, after two weeks the pane1 was ignited along the lower drift. Within 10 days the $f$ refronts joined and continued to burn as one broad front. However, the product gas remained essentially the same, largely the product of complete combustion.

In an attempt to make the fire hotter; oxygen was added to the blast. There was no change in the product. Oxygen was supplied from cylinders on the surface to make a $47 \%$ oxygen mixture. It was impossible to maintain the blast volume that had been available using ordinary air, and, because of this and other difficulties, the oxygen experiment was terminated after only $3 \mathrm{hr}$, before the temperature at the fireface had time to increase appreciably. The Lisichansk engineers realized that this did not 
constitute an adequate test of the oxygen-enrichment scheme. After 4 mo of operation, diagnostic boreholes were opened up to the seam and gas was removed from one of them. As has been the case at Krutova and Shakhty, the gas contained CO (Table 1). Further experiments with altered blast cycles were conducted to determine the effect on the quality of the gas issuing from the borehole. The results were very similar to those at Shakhty.

A brief experiment was conducted a Lisichansk on April 24, 1934. A single hole was drilled from the ground surface to the coal seam, and both blast and gas removal pipes were contained in this borehole, similar to Ramsey's proposal approximately 20 yr earlifer. An oxygen blast was used, causing a hole $1.5 \mathrm{~m}$ deep and $0.6 \mathrm{~m}$ wide in the coal. Because of the intense heat of the process, the exhaust pipe melted after $3 \mathrm{hr}$ and the experiment had to be terminated. At this stage, the product gases were still largely those of pyrolysis, with a heating value of $2250 \mathrm{kcal} / \mathrm{m}^{3}$. However, because of the high temperatures, the hydrocarbons were essentially all cracked $\left(0.3 \% \mathrm{CH}_{4}, 56 \% \mathrm{CO}\right.$, and $\left.1 \% \mathrm{H}_{2}\right)$.

\section{Channel Gusification}

In 1933, Podzemgaz announced an al1-union competition for the best underground 'coal gasification plan. ${ }^{1}$ In response to this competition, a group of workers, V. A. Matveev, P. V. Skafa, D. I. Filipov, and I. E. Korobchanskiy ${ }^{*}$ from the Donets Institute of Coa1 Chemistry (DUKhI) 11,22 suggested gasifying coal in a channel. Their plan assumed that gasification of unbroken coal could be carried out

\footnotetext{
*I. E. Korobchanskiy holds the two Russian patents in this process. "Subterranean Gasification of Coal" Russian Pat. 44294, Sept. 30, 1935, and "Underground Gasification of Solid Fuels," Russian Pat. 53992, 1938.
}

in a channel in the seam just as successfully as that of broken coal in a gas generator, because, as the air moves along the heated surface of the channel, the reaction of fuel gas formation should take place much as it does in a bed of fuel in a gas generator. (See Appendix A and Ref. 19.)

The DUKhI engineers proposed mining a channel along the strike some tens of meters deep in a steeply dipping coal seam at the Donets Basin. This channel was to be intersected at each end by sloping channels mined upward along the dip (toward the surface). These were connected to 
the surface by vertical boreholes or shafts (Fig. 6). (These terms are used in their usual mining sense. A borehole is a vertical or inclined hole that is drilled. A shaft is one that is mined. A drift is a horizontal channel, parallel or nearly parallel to the strike of the seam.) The three mined channels would limit the part of the coal seam (panel) to be gasified. Fire initiated in the horizontal drift would burn from the bottom to the top of the seam, the fireface moving gradually up dip. As the coal seam burned out, the channel, would widen and the coal and roof strata would collapse into the burned out space leaving the fireface free. The cross section of the fire channel itself would change very little with time, and the reaction would be sus-

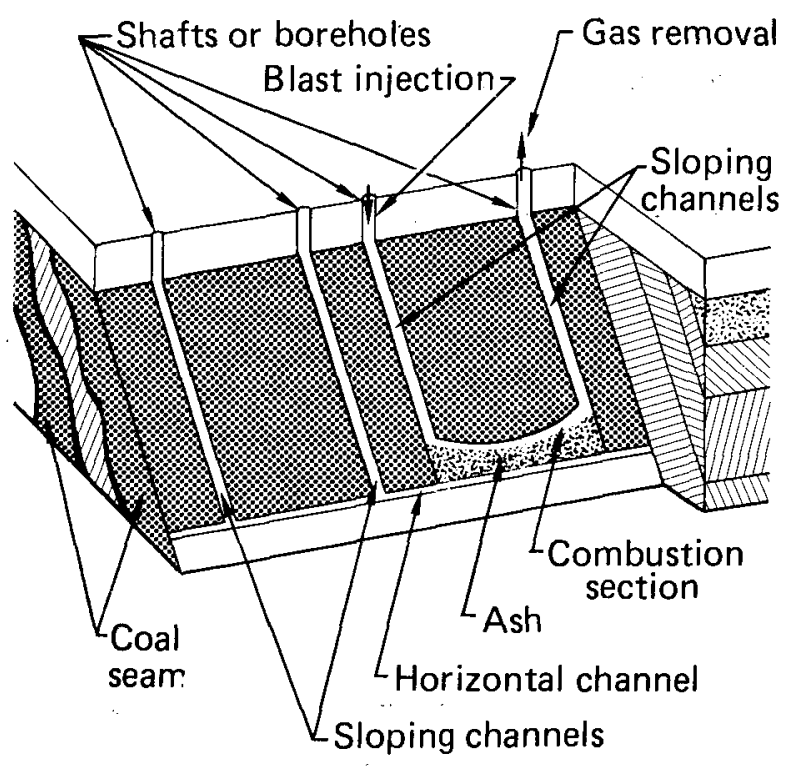

Fig. 6. The Stream method for gasifying coal in steeply dipping beds as proposed by the engineers from DUKhI. tained by supplying air from one end of the channel and withdrawing the product gas from the other end. This process was referred to as the flow or stream method.

In December 1933, workers at DUKhI conducted a laboratory experiment with a single $20 \mathrm{~kg}$ block of coal to test their theory of gasification. A horizontal borehole drilled part way into the coal block intersected a vertical borehole. The coal was ignited and an oxygen blast was introduced through the horizontal hole. Throughout the experiment that lasted a few hours, gas with a heating value of 2000 to $3000 \mathrm{kcal} / \mathrm{m}^{3}$ was extracted from the vertical borehole.

A laboratory experiment simulating conditions in the steeply dipping coal seams of the Donets was conducted at DUKhI in May 1934. A horizontal channel $90 \mathrm{~cm}$ long was mined together with channels $50 \mathrm{~cm}$ long running up dip. As in all the DUKhI experiments, oxygen was added to the blast to increase the heat of the reaction. Other experiments were conducted using Gorlovka coal. Based on the success of these experiments, a project for underground gasification using the DUKhI, or stream, method was begun in the Gorlovka region of the Donets Basin.

On June 27, 1934, while the first underground trial using the chamber method was in progress, the first 
DUKhI experiment was repeated at the Lisichansk Laboratory using air blast instead of oxygen as the reacting gas. The coal was taken from the seam being gasified in situ. The experiment ended after $2 \mathrm{hr}$ when the roof of the block caved in. The gas composition improved as the experiment progressed, reaching $62 \% \mathrm{CO}$ and $25 \% \mathrm{H}_{2}$ by the time the experiment ended. 23 The laboratory experiment was very carefully observed, studied, and documented.

To further test this method, two additional laboratory experiments were conducted at Lisichansk. In both of these experiments the horizontal hole extended all the way through the coal block. Gas quality improved as the blast intensity increased, with no upper limit observed. At the maximum blast intensities, * gas of about $1200 \mathrm{k} \cdot \mathrm{cal} / \mathrm{m}^{3}$ was

obtained.

During a period of several months beginning in July 1934, workers at Lisichansk conducted similar experiments underground in an area adjourning the panel being gasified by the chamber method 24 (Fig. 5). In the first of these underground borehole experiments, gas leaked into inclined

\footnotetext{
*Blast intensities as such are not given in Kirichenko's report, ${ }^{23}$ only overpressures. The maximum pressure at the input end of the borehole is given as $0.5 \mathrm{~atm}$ overpressure for the last experiment.
}

shaft number one. In fact, when the borehole was ignited near the east end, the gasification zone moved toward the inclined shaft instead of along the borehole. For the next experiment, elaborate fittings were installed in each end of borehole number two of the same area (Fig. 5). Nevertheless, such large leaks deve1oped that the experiment was terminated after $2 \mathrm{hr}$; all of the product gas was escaping into the upper channel. Attempts were made to better isolate the borehole from the channel, and the experiment was begun again in borehole number two. It lasted about $25 \mathrm{hr}$. As in the laboratory experiments, the heating value depended on the blast intensity. With main blast intensity, gas with a heating value of $1000 \mathrm{kcal} / \mathrm{m}^{3}$ was obtained. $^{24}$ Four trials were conducted in borehole number three. It was observed that the gas quality could be improved by heating the blast and adding oxygen or steam. (IT ho first two cases, the reaction temp:-.. $x$ sncreased, favoring the formation of $\mathrm{CO}$. The addition of steam led to hydrogen formation through the water-gas reaction. For a complete discussion of these reactions see Ref. 19.)

The laboratory and sma11-scale experiments at DUKhI and Lisichansk (in which coal was gasified in a channel cut out of an otherwise 
undisturbed coal seam) produced gas of reasonably high heating value in a more or less continuous, predictable manner, demonstrating that there was a better technique than the chamber method for gasifying coal in situ. These experiments led the Lisichansk engineers to plan the underground gasification of panel number three using a series of boreholes (Figs. 7 and 8 ). The system proposed by the Lisichansk engineers differs from the original proposal of channel gasification offered by the engineers
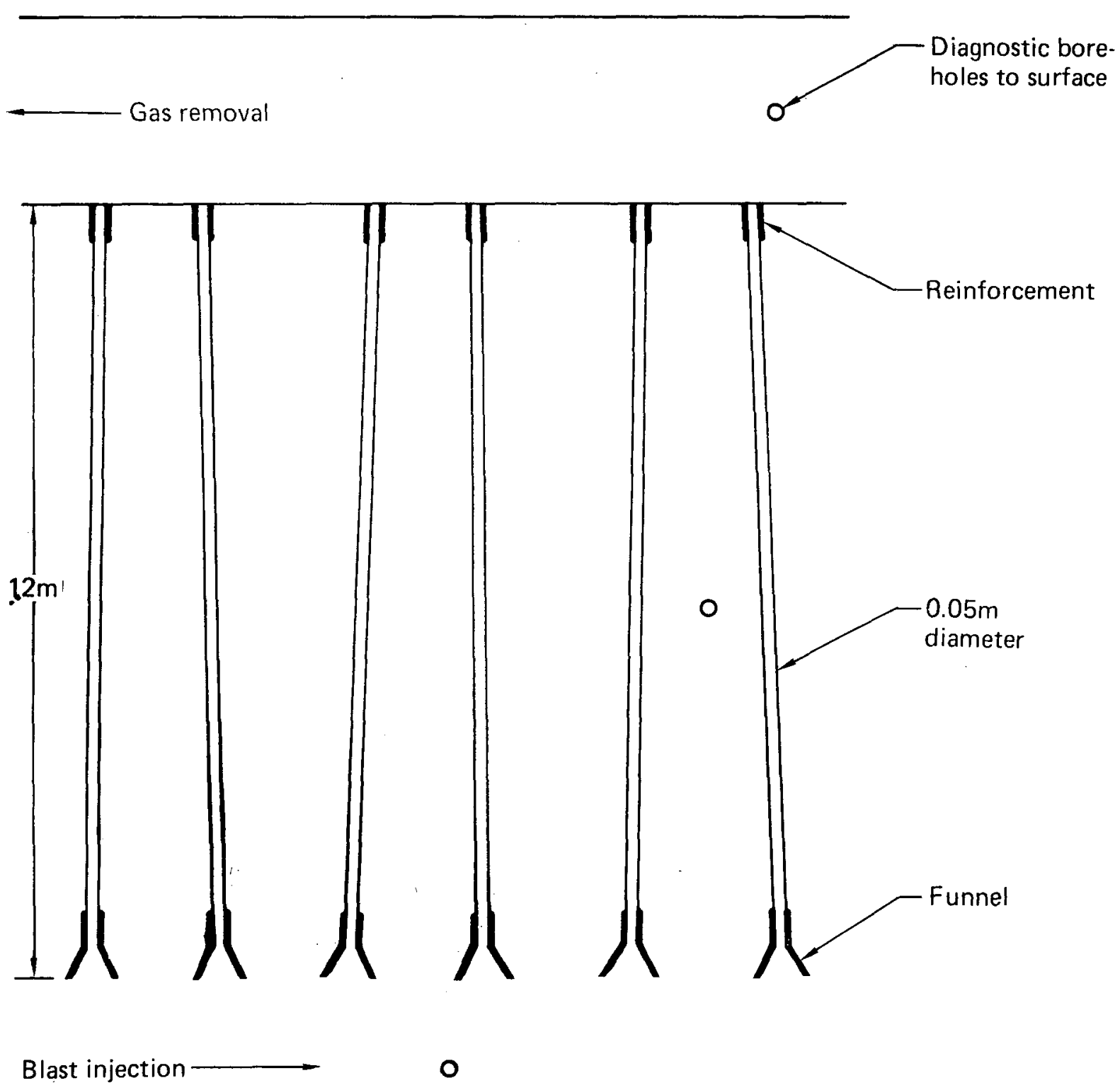

Strike

Fig. 7. Plan view of gasification experiment using a series of boreholes. 


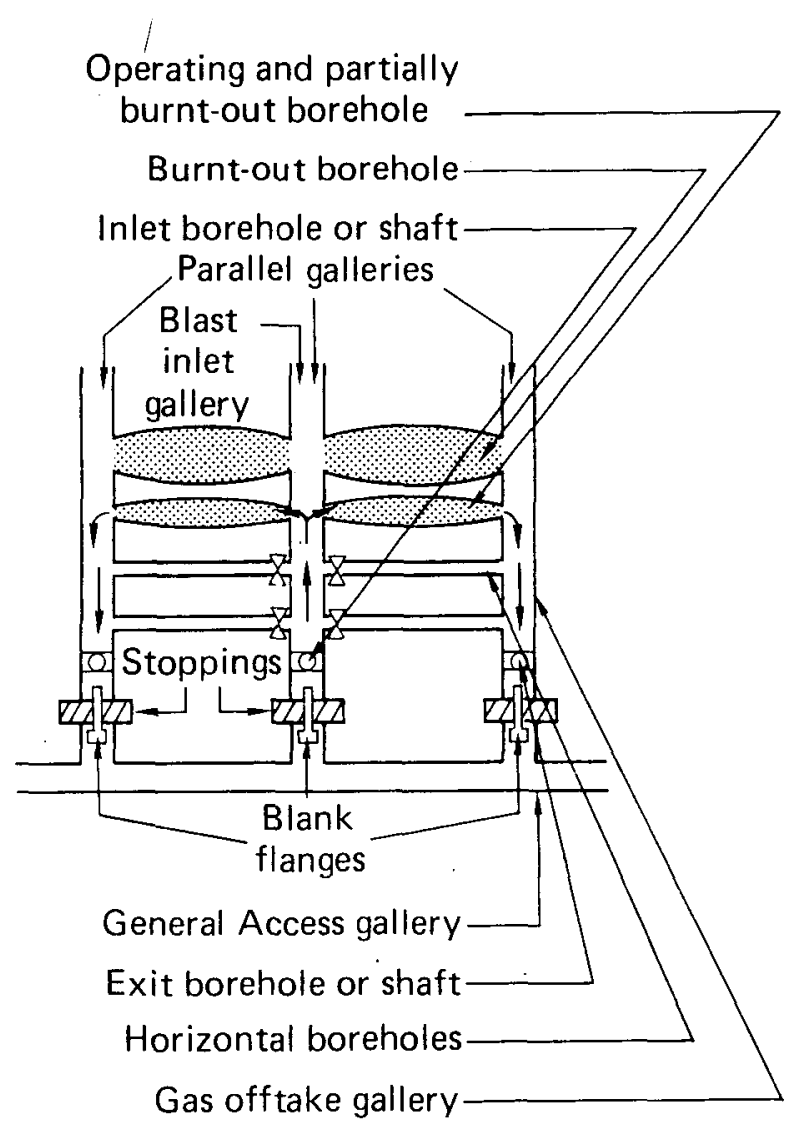

Valves 8

Fig. 8. The borehole producer method.

of the DUKhI. The engineers at the DUKhI envisioned the process of gasifying coal in a channel not as a panel composed of a series of boreholes, but rather as a single long channel mined at a depth of some tens of meters along the strike of one of the steeply dipping coal seams of the Donets Basin.

As mentioned previously, the borehole experiments at Lisichansk were conducted concurrently with the underground gasification experiment using the chamber method. In November and December 1934, the final experiment was conducted using the chamber method to gasify an underground panel at Lisichansk. For this experiment the coal was removed from the panel, crushed underground by hand, replaced in the panel, and gasified. As in the earlier experiments, severe problems resulted from channeling and bypass within the panel as well as from leaks around the outside of the pane1, and around the walls and pipes. Good quality gas could only be obtained from a borehole tapped into the chamber. The production of gas with a good heating value was very limited and was not at all continuous because the process was unstable and uncontrollable. These undesirable features were compounded by the complicated and expensive underground labor involved in building the furnace and crushing the coal.

\section{Borehole Experiments}

In the fall of 1934 , scientists

at Lisichansk begin preparing for the first trial using a series of bore- holes. Two parallel passages 1 to $3 \mathrm{~m}^{2}$ in cross section were mined along the floor of the seam. If the 
two passages were different sizes,

the larger channel, or drift, was used for the air supply and the smaller was used as the gas collecting drift. A series of parallel boreholes, 50 to $100 \mathrm{~mm}$ in diameter and separated by 1 to $1.5 \mathrm{~m}$, were drilled to connect these two passages

(Fig. 7). The borehole openings were fitted with iron pipes to prevent premature burnout, collapse, and, therefore, failure of a borehole. The passages were sometimes lined with heavy timbers because of the danger of cave in and plugging by debris falling in from above. The blast and product gas were carried into the drifts in pipes of $200 \mathrm{~mm}$ in. diameter. In general, each pipe was fitted with a valve so that each hole could be gasified independently. The product gas was removed through the shaft connecting the gas drift with the surface.

To insure that the process occurred inside the boreholes, they were ignited from within by elaborate electric resistance type igniters, that were switched on from the surface. After ignition, the coal burned radially along the walls of the boreholes, enlarging each hole into a cigar shape (Fig. 8). As the borehole enlarged, the basic characteristics of the process changed, and the quantity and quality of the product gas changed. To maintain the same stream velocity from an enlarging borehole, the blast intensity was increased. Hence, the intensity of the process and the temperature increased, and the gas quality improved. As the channel continued to widen, the transfer rate of oxygen to the burning coal surface diminished, but the radiativé heat loss from the burning surface remained constant or increased. As the surface (reaction) temperature decreased, the gas quality lowered. Eventually, coal surface combustion could no longer be sustained and the channel stopped growing. At a dimension somewhat larger than the seam thickness, ${ }^{25}$ the fire extinguished and the blast channeled straight through the borehole if the borehole was not closed off. The borehole method of gasification would produce a greater channel diameter if the blast were enriched with oxygen. ${ }^{*}$ An oxygen mixture increased the critical channel width by the about a factor of two. (See Ref. 19 for a more complete discussion of the basic principles of channel gasification.)

The first borehole experiment showed the Lisichansk scientists that by controlling the blast parameters (e.g., rate of flow, steam-oxygen

\footnotetext{
*If oxygen is added to the blast in the linking process, the link channel has a smaller diameter than is the case for an air blast. 22
} 
contents, blast pressure) they could control the gasification process. Because they could determine how large the borehole would become, they could plan the size of the panel to maximize resource recovery and minimize the danger of subsidence. A gas of uniform quality could be maintained from the panel as a whole using several boreholes and igniting each one in succession when the degree of burnout in the preceding borehole reached a certain point.

The chief problems with this method were: 1) gas leaks into surrounding strata via fissures from the borehole itself and from the seals between the pipes and boreholes, 2) channeling, and 3) inability to manipulate the borehole valves, causing limited surface control of the underground environment.

As in 1933 with the chamber method, the workers at Krutova were the first to carry out an experiment employing the method described by the group at Lisichansk. Gasification using the borehole method began at Krutova on January 6,1935 . The paralle1 channels were $12 \mathrm{~m}$ 1ong, separated by $1.2 \mathrm{~m}$. The firedrift was 1.8 by $1.6 \mathrm{~m}$ in cross section, and the gas collecting drift was 1.0 by: $1.3 \mathrm{~m}$. The six boreholes were 50 to. $50 \mathrm{~mm}$ in diameter. The experiment lasted six days. Even though the brown coal was exceedingly (wet as much as $30 \%$ water) an air-steam mixture was used as the blast. The blast was cycled on and off, producing gas during the off period with a heating value of $730 \mathrm{kcal} / \mathrm{m}^{2}$. During the on period, gas was obtained with a heating value of $420 \mathrm{kcal} / \mathrm{m}^{3}$, while a continuous air blast produced gas with a heating value of $500 \mathrm{kcal} / \mathrm{m}^{3}$. (In his summary, Sazonov ${ }^{19}$ gives a heating value of $1300 \mathrm{kcal} / \mathrm{m}^{3}$; however, his tables show a maximum value for the lower heating value of $730 \mathrm{kcal} / \mathrm{m}^{3}$. In a review written in 1957, Skafa ${ }^{21}$ reports a value of $1100 \mathrm{kcal} / \mathrm{m}^{3}$. This is most likely an error.)

The experiment at Krutova was conducted rather hastily. Because the trial panel was located near an old mine there were cave ins and gas leaks into the worked-out area, causing the experiment to be terminated prematurely. Only about $25 \%$ of the coal in the panel was gasified.) ${ }^{26}$ No coal analysis was made nor any records kept of the amount of steam supplied. For these reasons, material and thermal balance could not be calculated. However, the experiment. did demonstrate that gas of reasonable quality, up to $.720 \mathrm{kcal} / \mathrm{m}^{3}$, could be obtained from the low grade coals of the Krutova seam.

In May 1935, a second panel at Krutova was gasified using boreholes, and the product gas quality was 
roughly the same as that from the previous experiment. Again, combustible gas was obtained only intermittently, and stable operation was never achieved. After this experiment, the station at Krutova was abandoned and there was no further experimentation in the Moscow basin until 1940 , when a commerical station using the stream method was opened near Tula.

An experiment at Lisichansk using a series of parallel boreholes began in April 1935. The parallel drifts were mined along the strike. Five boreholes $75 \mathrm{~mm}$ in diameter, $12 \mathrm{~m}$ long, and separated by $1.5 \mathrm{~m}$ were drilled up dip from the lower (fire) drift. Each borehole was supplied independently with air and water (or steam). All the boreholes emptied into a common conduit in which the gas was constantly monitored for temperature and content. On several occasions the temperature at the gas outlet rose from 700 to $900^{\circ} \mathrm{C}$. This was attributed to oxygen passing through some of the holes, without reacting with the coal, thus causing combustion in the exit gas collector. Indeed, in each case, the temperature was lowered to $700^{\circ} \mathrm{C}$ when the suspect holes were shut off. Pieces of clinker, or coke, were blown into the exit gas pipe on several occasions, causing temporary plugging that was usually cleared by shutting off the input blast. After 12 days, however, the pipe became completely plugged and the experiment has to be terminated. The average heating value of the gas obtained during the 12 days was $870 \mathrm{kcal} / \mathrm{m}^{3}$, and gas quality was found to be blast dependent. With a flow rate of $1700 \mathrm{~m}^{3} / \mathrm{hr}$, gas with a heating value of $1300 \mathrm{kcal} / \mathrm{m}^{3}$ was obtained. As with the previous experiments at Lisichansk, the work was very careful and complete. Material balance calculations showed that about $33 \%$ of the coal was gasified completely, and an additional 50\% coked. These values compared favorably with the later observations made when the panel was opened.

A month later, another borehole experiment was conducted at Lisichansk in which three boreholes $25 \mathrm{~m}$ long, $100 \mathrm{~mm}$ in diameter, and spaced at $2.5 \mathrm{~m}$, were drilled directly up dip. The gas circuit was modified to prevent pieces of coke from lodging in the gas exit conduit and blocking the flow. In this experiment the boreholes had a common blast supply and apparent1y could not be closed off by valves in the conduits. Problems with channeling and by-pass were not mentioned, although they were noticeable in previous boreholes trials and were expected. The average lower heating value was $825 \mathrm{kcal} / \mathrm{m}^{3}$, representing about $40 \%$ energy recovery in the coal. Calculations showed 
that $55 \%$ of the coal gasified completely and $45 \%$ coked. This agreed wel1 with observations made when the panel was opened. (Within $4 \mathrm{~m}$ of the borehole inlet, the hole diameter was $1.5 \mathrm{~m}$ with a 26 or 27 cm-thick cylindrical shell of coke and partially burned coal surrounding the cavity.)

A variation of this method of using a series of boreholes was proposed by Zhuralev in 1934 and tried at Chelyabinsk in the Urals in 1935. The channels carrying the blast and product gas were mined below and above the coal, with the connecting boreholes lying more or less vertically in the seam. Gas with a heating value of $1425 \mathrm{kcal} / \mathrm{m}^{3}$ was obtained at a gasification rate of $2000 \mathrm{~m}^{3} / \mathrm{hr}$ of coal gasified. ${ }^{1}$ Very little information is available concerning Zhurakev's method or any of the experiments conducted at Chelyabinsk.

\section{Leninsk Experiment Using the Stream Method}

Although scientists from the

Donets Institute are usually mentioned in connection with the stream method, the method of coal gasification in a channel was proposed independently by B. F. Grindler in 1932 and published in Ugol Vostoka (Eastern Coal) in 1933 in an article entitled "Methods and Means of Implementing the Idea of an Underground Gas Generator at Leninsk." 27 In June 1934, after nearly two years of preparation, experimental gasification using the stream method was initiated in a flat portion of a seam in the Leninsk mine located in the Kuznets Basin (Fig. 9). Fire was ignited in three hollows in the mined channel that surrounded the coal panel on three sides. The channels were large and unlined and air was supplied with a single $3000 \mathrm{~m}^{3} / \mathrm{h}$ blower located in shaft number 2 . The gas exited through shaft number 1. Because of the large coal panel and the limited air supply, the fire spread slowly at first, finally forming an extended fireface. However, the limited blast caused the fireface to move toward the input and burn along the northern wall of the panel, instead of along the eastern wall as planned. 28 No provisions had been made to dewater the gasification area and water intrusion apparently lowered the reaction temperature so that large quantities of $\mathrm{CO}_{2}$ were formed. Analysis equipment at Leninsk was very limited and rudimentary. For this reason, perhaps a11 of the gas analyses are suspect. 


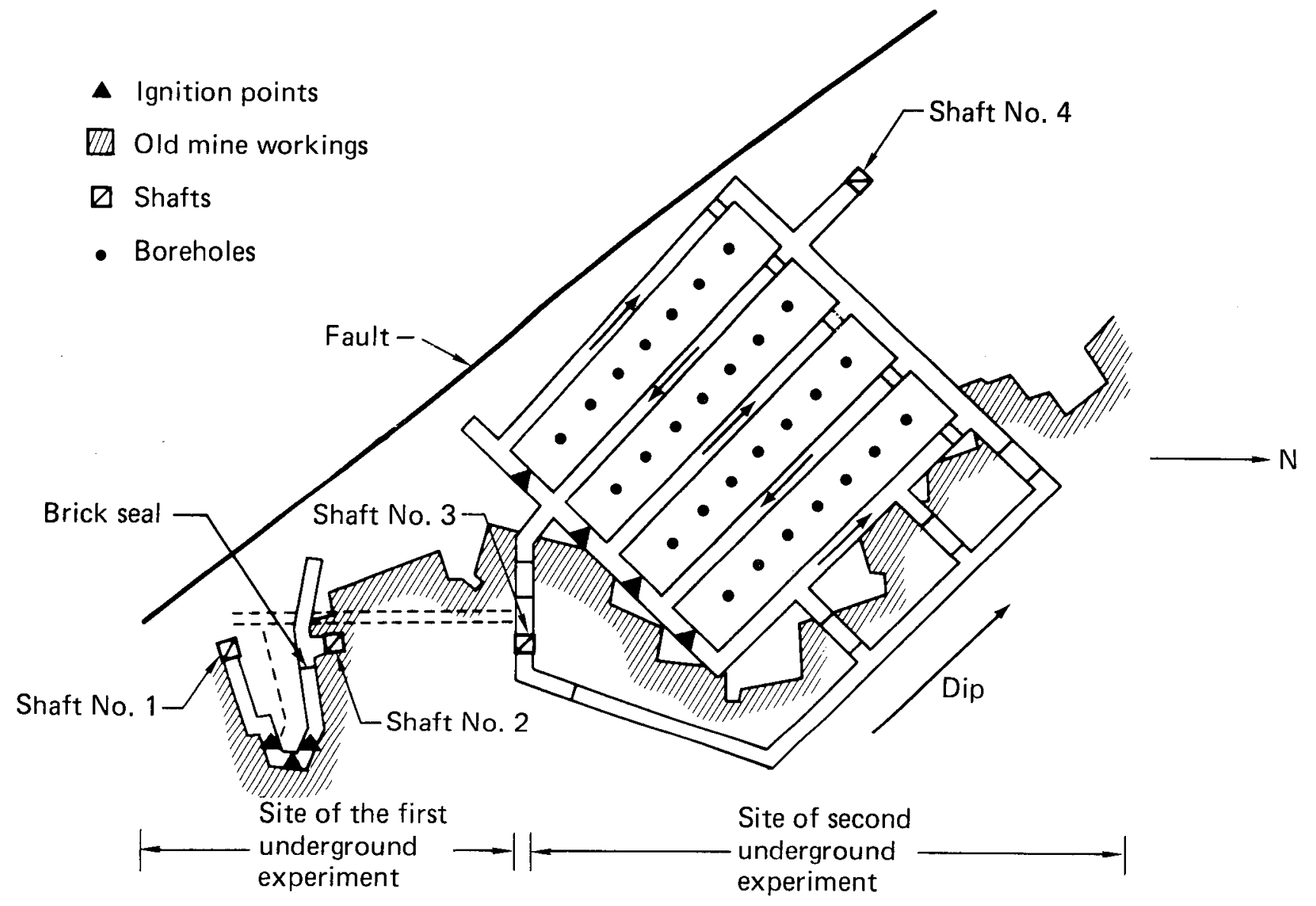

Fig. 9. Plan view of the underground coal gasification area at Leninsk.

In general, the first experimental panel at Leninsk burned in a continuous manner, producing high quality gas for about five months. Approximately half of the coal was gasified, as indicated by the broken line in Fig. 9. Then the roof caved in, allowing part of the input blast to channel through the rubble, oxidizing the product gas. The gasification trial was then terminated.

Because of the high quality gas (up to $4000 \mathrm{kcal} / \mathrm{m}^{3}$ ) obtained from the diagnostic boreholes in the first underground gasification trial at
Leninsk, many writers feel that the coal was not completely burned, but was merely pyrolized due to an inadequate blast supply. (Table 1 shows that the coal has a high percentage of volatiles. Note also that the quality of the gas reaching the surface through the main off-take pipe was not as high, $2000 \mathrm{kcal} / \mathrm{m}^{3}$.) One reviewer stated that perhaps as much as $85 \%$ of the coal energy remained underground in the form of unburned coke and tars. 29

B. F. Grindler, "scientific director of experimental work" at Leninsk, 
dismissed this claim as simply the rantings of those distressed at the succes of a project that gasified "pillar coal without the coal being first granulated." In Ugol Vostoka he stated, "The entire coal mass has been converted into clinker and ash, and not into coke." 27

Although the final assessment of the first experiment at Leninsk remains uncertain, it did prove that coal can be gasified using the flow method. For the first time, gas produced underground was used in a practical way. For 38 days it drove a steam boiler, heated and supplied power for nine service units, a bath house, club house, lamp station, and workshop. 28 similar to previous experiments using the chamber method, the quality of the gas obtained in the first Leninsk experiment was reduced because of channeling and bypass of the blast around the fireface. With the stream method, however, this problem could be avoided by using conduits to carry the blast to the fireface and the product gas from it. These conduits were used in the second Leninsk experiment and in many future trials that used the stream method. This method also introduced a means of controlling underground gasification by regulating the gas flow and delivering it to and from the fireface instead of letting it spread uncontrollably throughout the formation. This first experiment also showed the necessity for dewatering, as well as the need for methods of site preparation that would allow for proper gas circulation regardless of subsidence.

The second trial at Leninsk using the stream method began in April 1935, and ran for about six weeks, producing gas of remarkably uniform heating value. The experiment was carefully designed to eliminate the problems that had plagued all of the earlier experiments (Fig. 9). Four parallel panels $58 \mathrm{~m}$ long by $9 \mathrm{~m}$ wide were marked off by mined-out channels. Gas from the four panels was mixed to reduce variations in the product gas quality; subsequently, the gas was cooled to eliminate the water through condensation and was then passed through a tar trap. ${ }^{30}$ (In his 1909 patent, Betts had suggested that several parallel gasification panels could provide a fairly uniform quality gas, maintained simply by mixing the products from several panels in different stages of gasification.) Large pipes ( $300 \mathrm{~mm}$ in diameter) were laid in the channels to carry the air to the fireface and the product gas from it. This eliminated channeling and bypass of the air around the reaction zone as well as the movement of the reaction zone upstream toward the blast inlet shaft. In addition, the pipes were used in an attempt to 
reduce gas leaks. The conduits were constructed of alternating sections, of heavy steel pipe and thin steel pipe, each about $3.75 \mathrm{~m}$ long. The sections of heavy steel were held in place by brick bulkheads built in the channels at intervals of $7.5 \mathrm{~m}$. The heavy pipe was designed to last until an area was entirely burned out before it would be crushed by subsidence. The thin pipes were lined with thick wooden boards and then held in place by boards and clay. As the fire burned its way through the panel, the sections of thin pipe melted away, always bringing the ends of the blast and withdrawal pipes to the fireface. The geological characteristics of this area made these features especially valuable. The area adjacent to the gasification panel had been previously mined, the bed was highly fissured, and the area suffered from subsidence and cratering. The coal itself was thermally unstable and easily ignited spontaneously. ${ }^{31}$ By running both input and output pipes through shaft number four (Fig. 10), the input gas could be preheated, improving the efficiency of the process by increasing the temperature in the reaction zone. This caused an increase in the heating value of the product gas. Shaft number three served as a dewatering we11, and while it is not clear which method of dewatering was used, it is known

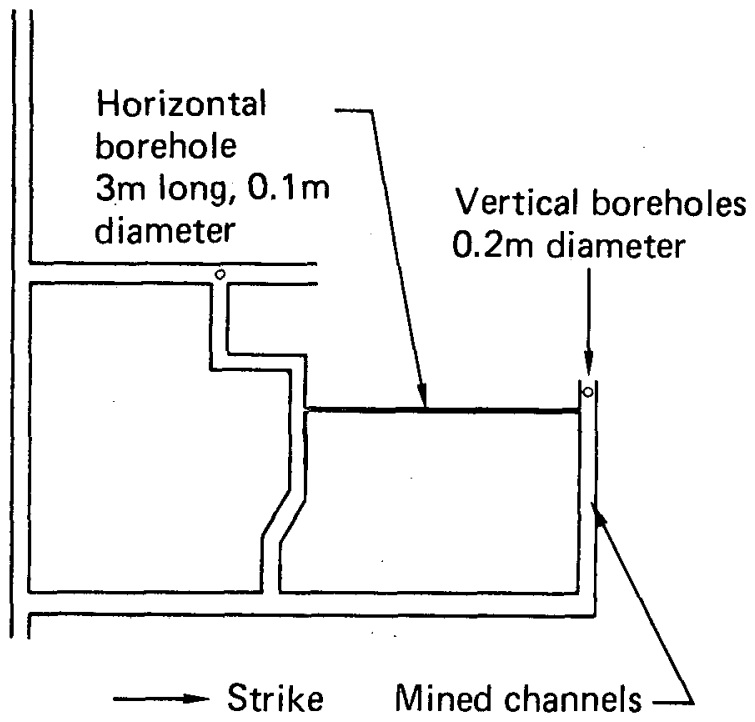

Fig. 10. Plan view horizontal borehole experiment at Lisichansk.

that the water level was quite high during the second experiment. (Perhaps the excess water resulted from spring rains and run-off. ${ }^{31}$ At any rate, the reaction zone was cooled considerably by excess water.)

Twenty-six diagnostic holes, each $75 \mathrm{~mm}$ in diameter, were drilled to the floor of the coal seam (Fig. 10). Unfortunately, the holes nearest the fireface were still 6 to $8 \mathrm{~m}$ from it, and therefore, the temperature profile of the initial coal warmup could not be observed. Monitoring and control were centrally located. (From the emphasis on this point in the original report, one can conclude that this was an innovation in underground coal gasification tests.)

Before initiating the gasification process, the engineers at Leninsk had calculated the blast necessary to 
supply the initial fireface. (At Leninsk the blast was air with no oxygen enrichment.) Even though the blowers were known to be inadequate, especially for initiation, it was decided to proceed with the experiment. One week was required to initiate and stabilze the process and another week to dry the coal enough to permit useful production. Then, in the following four weeks, the Leninsk experimental panel supplied two million $\mathrm{m}^{3}$ of fuel gas with a heating value of 900 to $1100 \mathrm{kca} 1 / \mathrm{m}^{3}$.

The experiment was terminated after six weeks because of inadequate blowers and subsidence problems, resulting in gas leaks into the old workings and crushed pipes in the eastern-most channel. (It is possible. that subsidence was worse due to the proximity of the old mine.) Apparently, very little underground work would have been necessary to continue the second experiment, and on the surface, only additional blast capacity was necessary. The scientific writers at Leninsk argued the feasibility of continuing to gasify this coal, claiming that the Leninsk station could supply a uniform quality gas in commercial quantity for a year and a half. Since 1934, one of Grindler's critics, V. Alekseyev, had argued that a gasification station at Leninsk was inappropriate because there were no major consumers nearby, while at Stalinsk and Kemerova industrial centers were being developed. Alekseyer also argued that Leninsk coal was of too high quality to burn underground, and that the seams at Leninsk were flat while most of those in the Kuznets were steeply dipping (40 to $70 \mathrm{deg}$ ). Therefore, the experience gained at Leninsk would be of little general value for underground coal gasification in the Kuznets Basin. Apparently, Alekseyev's arguments prevailed because the second Leninsk experiment was never continued. Underground gasification in the Kuznets Basin ended until the Yuzhno Abinsk station opened near Kiselevsk in 1955 . $^{32}$

Regardless of the practicality of conducting underground gasification experiments at Leninsk, this second trial had proven that the stream method was predictable and controllable: (The product gas had a very constant heating value.) There was an ignition channel that provided stable and continuous supply and withdrawal of gas: The blast flow could be directed to the desired location, channeling was eliminated, and leakage was minimized. The flow of blast to the fireface could be varied, thus helping to maintain a constant gas quality. Furthermore, the Leninsk trials demonstrated that the stream method could be used in essentially flat seams. In fact, 
those working on the stream method in the Kuznets felt that this design was most appropriate to their flat beds. One author said that if the seam were steeply dipping, the panel should be lit from the side along the dip, instead of from the end along the strike 30 as originally suggested by the engineers from DUKhI.

(A system very similar to that used in the second Leninsk trial was used in the first industrial opera- tion, a pre-Wor1d War II installation located in the flat seams of brown coal in the Moscow Basin. Apparently, the bulkheads were eliminated and the pipe structure was simplified. The gas conduits were heavy steel pipes, perforated at intervals along the axis on the side nearest the pane1. The pipes were wrapped with a tin sheath and covered with asbestos. As the fire burned, the thin metal sheath melted away, always bringing the blast to the fireface.)

\section{Final Borehole Experiment (Stream)}

In January 1936, a final borehole experiment was conducted at Lisichansk, in which a borehole was drilled along the strike, instead of along the dip as in all the previous cases (Fig. 10). The borehole was connected to the surface by old workings and vertical boreholes. In its early stages, this experiment proceeded like the others in which gasification took place in a single borehole. The borehole at first widened into a cigar-shaped channel, but as it widened the experiment began to follow the classic design of the stream method. (In Fig. 10 note the $U$ shape of the old workings and horizontal channel.) After 25 days the fire was extinguished and the area was opened (Fig. 11). The excavation of this hole provided much useful information concerning underground gasification with the stream method in steeply dipping beds.

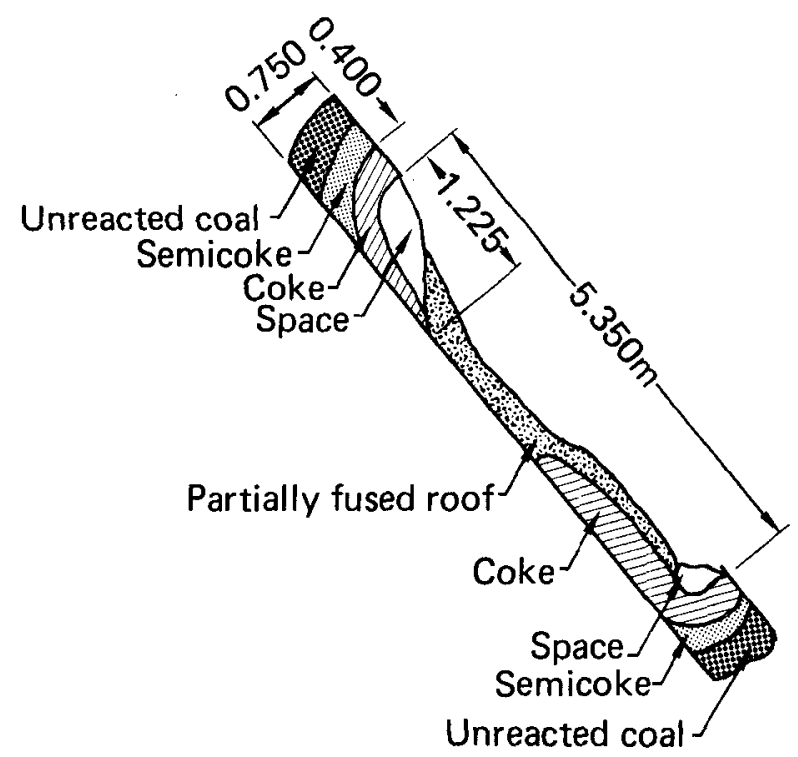

Fig. 11. View of a channel gasification experiment at Lisichansk that was opened for inspection. 
There was a void near the coke, permitting contact between the blast and the reacting surface. ${ }^{33}$ Although a layer of rocks had caved in, the roof structure in general was intact.
The space created as the coal burned away allowed a sizable portion of the blast to by-pass the fireface. ${ }^{34}$ This pattern of subsidence later proved to be common at Lisichansk.

\section{Gorlovka Experiments Using the Stream Method}

The underground tests at Gorlovka were based on the stream method. In the first experiment a channel was mined along the strike at the $110 \mathrm{~m}$ level and connected to the surface by five inclined channels along the dip, separated by $25 \mathrm{~m}$. A British reviewer, Stuart Atkinson, ${ }^{35}$ writing in the April 1937 issue of Colziery Engineering, stated that the channels along the dip were steel lined to prevent cave-ins. Apparently, the panel to be gasified was somehow marked off at the $40 \mathrm{~m}$ level. (We were unable to find precise details of the layout of the Gorlovka experiments.). It appears, however, that the inclined channels in this first experiment extended all the way to the surface, rather than only to the $40 \mathrm{~m}$ level. (The design in Fig. 6 shows vertical boreholes or shafts intersecting the inclined ones at the $40 \mathrm{~m}$ level.) It is not clear whether all panels were contiguous as had been the case at Leninsk (Fig. 9) or whether only alternate coal panels were meant to be gasified (Fig. 6).
It seems probable that the panels were contiguous and only the central panels were gasified in the first experiment. In a review written in 1957, V. A. Matveev" reported "samples of gas taken from the intermediate boreholes supplied valuable data for studing the dynamics of gas formation along the length of the flame-face." 36 Although these boreholes are not shown in any available references, they were undoubtedly placed similarly to those shown in Fig. 10.

In constrast to the trials at Leninsk, the experiments at Gorlovka had good surface equipment that supplied an adequate blast. There were two compressors each capable of supplying $3500 \mathrm{~m}^{3} / \mathrm{h}$ of air at 6 atm. In addition, a cheap supply of oxygen was available from a synthetic fertilizer plant near the gasification station.

The first experiment at Gorlovka lasted three months, February to May 1935. Following an "interruption of three months made necessary by workings", 37 the panel was apparently 
relit and it supplied gas continuously for about 9 mo. The amount of oxygen enrichment in the blast varied between 21 and $80 \%$. Table 2, taken from a 1946 English review, ${ }^{1}$ shows the variation of the product gas with change in the oxygen enrichment. The same review reports that "The most satisfactory operation appears to have been attained with 27 to $30 \%$ of oxygen in the blast." 1

After an accidental interruption, it was discovered that a gas composed of 40 to $50 \%$ hydrogen and $15 \%$ nitrogen issued from the gasification site during the blast-free period. In the preceding period, during which a $37 \%$ oxygen enriched blast was being used, the product gas was $20 \%$ hydrogen and $44 \%$ nitrogen. (This is similar to the water gas production process often used in surface coal gasification generators. The bed of coal and coke is heated to a high temperature by the injection of the blast into the generator. Then the blast is shut off and steam is passed into the generator. The heat in the bed gives rise to the endothermic reactions between carbon and steam described in Appendix A. Because of the size of the heat reservoir in a surface generator, the blast and steam cycles each last for periods of a few minutes.) Using steam and a $37 \%$ oxygen enrichment in this cyclical manner, it was possible to alternately produce technological gas $\left(2400 \mathrm{kcal} / \mathrm{m}^{3}\right)$ and producer gas (1400 $\mathrm{kcal} / \mathrm{m}^{3}$ ) (Fig. 12). With an air blast, the heating value was 900 to $1000 \mathrm{kcal} / \mathrm{m}^{3}$; in the subsequent blastfree period, the heating value was $1600 \mathrm{kcal} / \mathrm{m}_{3}$. In general, 20 to $33 \%$ of the gas produced was technological gas and 66 to $80 \%$ was producer gas. Although the data from this experiment are often quoted, apparently the Soviets never performed another in situ experiment in which the blast was cycled on and off. ${ }^{*}$ Careful

\footnotetext{
* The use of a pulsating blast was suggested again in 1957,38 but there is no indication that it was seriously considered.
}

Table 2. Composition of gases made with varying oxygen content in the blast.

\begin{tabular}{|c|c|c|c|c|c|c|c|c|c|c|c|c|}
\hline $\begin{array}{l}\text { Comb. } \\
\text { agent } \\
0-\%\end{array}$ & $\mathrm{CO}$ & 0 & $\begin{array}{l}\text { Gas } \\
\text { CO }\end{array}$ & $\begin{array}{l}-\% \\
\mathrm{H}\end{array}$ & $\mathrm{CH}_{4}$ & $\mathrm{~N}$ & $\begin{array}{l}\text { Heating } \\
\text { value } \\
\mathrm{kca} / \mathrm{m}^{3}\end{array}$ & $\begin{array}{c}\mathrm{Ga} \\
\mathrm{CO}_{2}\end{array}$ & $\begin{array}{l}\text { s wit } \\
\mathrm{O}_{2}\end{array}$ & $\begin{array}{r}\text { hout } \\
\text { CO }\end{array}$ & $\begin{array}{r}-\% \\
\mathrm{H}_{2}\end{array}$ & $\mathrm{CH}_{4}$ \\
\hline 21 & 8 & 0.2 & 12 & 14 & 2.5 & 63.3 & 937 & 21.8 & 0.5 & 32.7 & 38.2 & 6.8 \\
\hline 30 & 12 & 0.2 & 20 & 19 & 3.5 & 45.5 & 1.391 & 21.9 & 0.4 & 36.5 & 34.7 & 6.7 \\
\hline 50 & 15 & 0.2 & 25 & 23 & 8.0 & 28.8 & 2.031 & 21.1 & 0.3 & 35.1 & 32.5 & 11.2 \\
\hline 70 & 20 & 0.2 & 28 & 30 & 10.0 & 11.8 & 2.472 & 22.7 & 0.2 & 31.8 & 34.0 & 11.3 \\
\hline
\end{tabular}




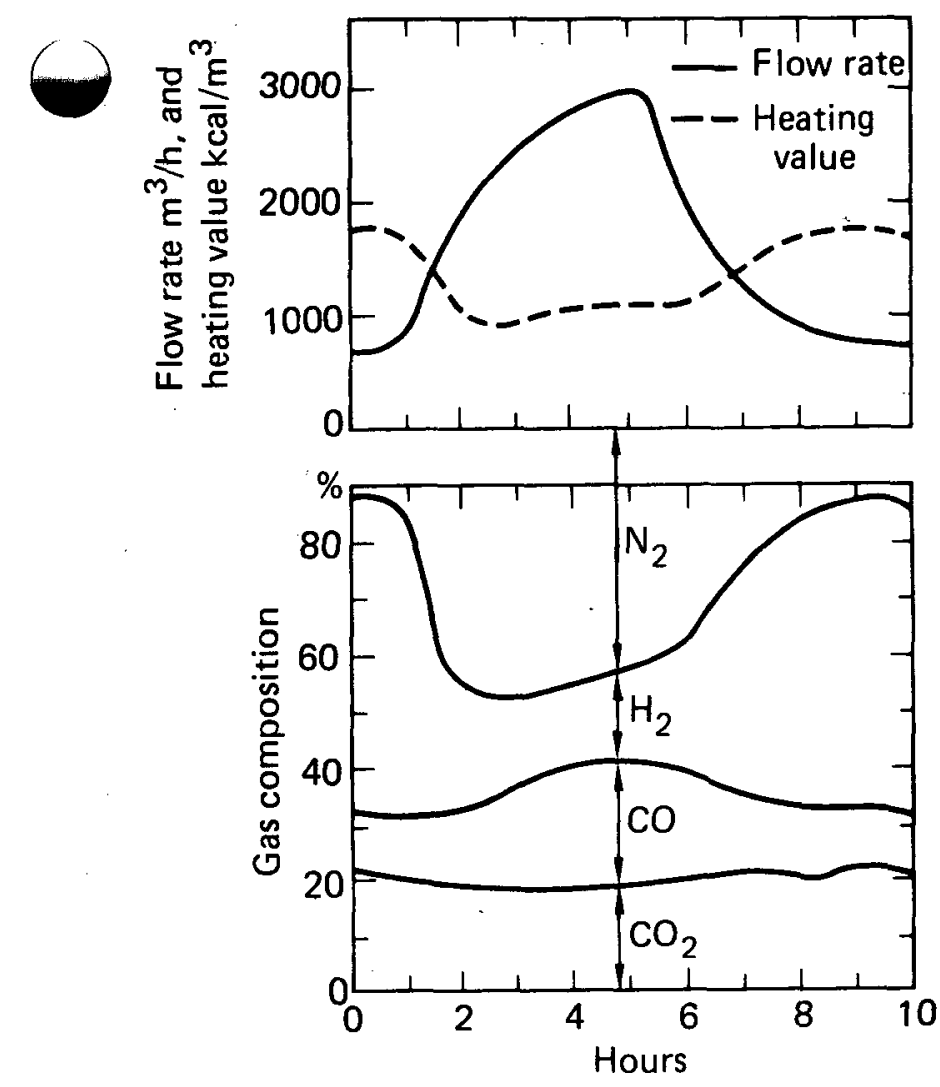

Fig. 12. Gas composition, flow rate, and heating value using an alternating blast cycle with 25 to $48 \% \mathrm{O}_{2}$ enrichment.

recording of the data permitted various analyses. For example, it was calculated that during the month of July 1935, the gas leaks amounted to only $5 \%$, that $1.75 \mathrm{~m}^{3}$ of gas were produced per $\mathrm{kg}$ of coal gasified, and that about $43 \%$ of the coal was gasified completely and $57 \%$ was coked. 37

There are no records available of the tests in panels two and three at Gorlovka, if indeed such tests were run. Panel four was located in a seam $8 \mathrm{~m}$ from the seam gasified in the first experiment. It was made up of a horizontal fire channel at the 110-m depth, three mined channels running up dip to the 40-m depth, and three vertical boreholes connecting the mined channels with the surface. The mined portion of each outer channel was unlined. However, the vertical boreholes were lined with steel tubing. The intermediate channne1, $50 \mathrm{~m}$ from the input side and $25 \mathrm{~m}$ from the output side, was lined with perforated tubing. In case there was a cave-in in the gas collecting drift, this central auxiliary channel could be used. We were unable to find information about panel four production.

Panels five and six were laid out in the design used in the first panel (Fig. 13). Each panel was $100 \mathrm{~m}$ long by $100 \mathrm{~m}$ wide, contained 20,000 tons of coal, and was separated from the other by a 40-m protection panel. The channels running along the dip were lined with perforated pipes $300 \mathrm{~mm}$ in diameter. The vertical boreholes were lined with 400-mm diameter pipes. Telescopic joints with asbestos packing allowed expansion:

$A n$ air stream was injected into each panel before ignition "in order to drive the entrapped $\mathrm{CH}_{4}$ and $\mathrm{CO}_{2}$ from it". 37 Then a 60 to $90 \%$ oxygenenriched blast was injected "to facilitate ignition." 37 We were unable to determine whether this latter practice was followed in later 
similar experiments; however, the practice of blowing with an air blast before ignition was used to dry the panel in many later experiments.

After about six weeks, panel five was producing a steady output of gas with a more or less uniform heating value. On several occasions large, temporary drops in the flow rate occurred because of plugged channels caused by cave-ins. At Gorlovka, the roof rock was instable and frequently caved in, causing numerous pockets that trapped the blast (resulting in poor contact of the blast and the reaction surface, as well as combustion of the product gas) and undesired reaction zones that formed above the main fireface. On one occasion, known to be caused by a plugged channe1, results were obtained that were similar to those from the cyclical operation of panel one; i.e., technological gas followed blockage. (Cave-ins at the fireface may have '.: temporarily increased the available reaction surface.) When the blast resumed there was a sudden drop in the heating value, (perhaps due to cooling of the combustion front, or the pyrolysis gases were possibly burned by the oxygen in the blast when it resumed). Power outages, damage to the compressors, or explosions in the channels caused various other interruptions. In general, however, gasification proceeded smoothly and was controllable. With a 21 to $25 \%$ oxygen enrichment, the lower heating value varied between 1000 to $1300 \mathrm{kcal} / \mathrm{m}^{3}$; with $60 \%$ enrichment it was $1700 \mathrm{kcal} / \mathrm{m}^{3} ;$ and with air it was to 800 to $900 \mathrm{kcal} / \mathrm{m}^{3}$.

During February and March 1938, the output from panels five and six was sent to the Gorlovka coke and

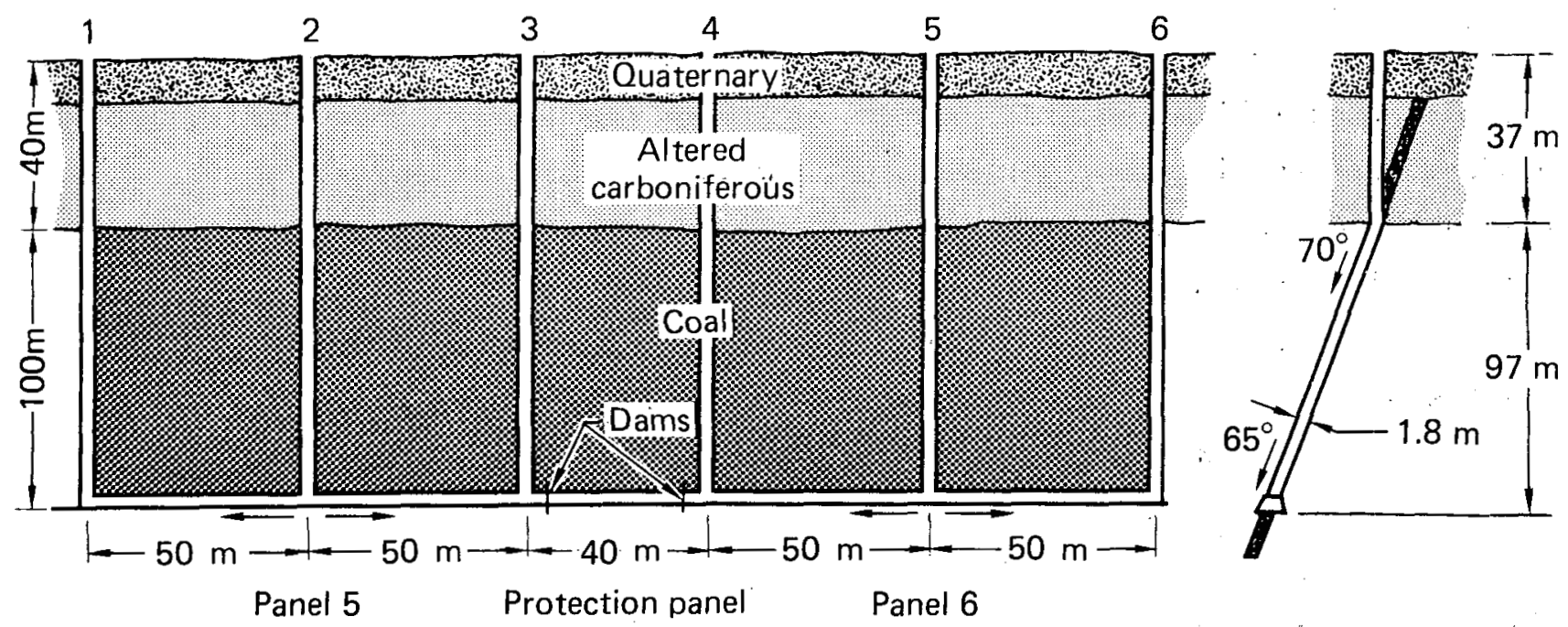

Fig. 13. Panels five and six from stream method experiments at Gorlovka. 
chemical plant where it was used in the steam,bollers and to heat the coke ovens. No reason was given for the discontinuation of the supply of gas to the coke and chemical plant with another 18 mo remaining in the life of panels five and six.

In 1939, gasification was started in panels seven and eight at Gorlovka. In this case, each panel was $175 \mathrm{~m}$ long and began at the $260 \mathrm{~m}$ level. The gas was supplied to an experimental gas turbine. (The first gas turbine for use in an electrical power plant was designed under the direction of $V$. Makovskiy at the Kharkov Mechanical Engineering Institute in the late $\left.1930^{\prime} \mathrm{s.}\right)^{35,39}$ Operation of the Gorlovka station continued until the German invasion. The safety pillar separating the underground coal gasification station from the area being mined, was badly damaged. Apparently, it did not seem feasible to reopen the station in the Gorlovka coal fields after the war.

\section{Commercialization}

From the beginning of the first small scale experiments, the Soviets were anxious to find productive uses for even the small quantities of gas produced. (The gas from the first Leninsk experiment in $1934 \mathrm{had}$ supplied the mine service units for over a month. In 1938, gas from two panels at Gorlovka had been used in a local chemical plant.) There was also a strong desire to build a large-scale gasification-system with substantial industrial capacity. As early as the second 5-yr plan (19331938), underground gasification was included in the program of industrial development. With the increased con- centration of interdependent branches of industry near the principal coal basins, the third 5-year plan (19381943) provided for the use of gas in power plants and chemical plants, and for communal domestic purposes. ${ }^{1}$

In a paper published in February 1936, A. S. Kuznetsov ${ }^{40}$ stated that "the Shakhty anthracite experimental mine was operating under instructions from NKTP [Peoples' Commissariat of the Fuel Industry] to carry out a large-scale trial, with gas production sufficient for operating a regional power station boiler having a heating area of $1000 \mathrm{~m}^{2}$ [Artem State Regional Power Station]." 40 Although 
this came at a time when the chamber method had proved to be "expensive and unreliable" 21 (gas of irregular quality, the result of channeling and by-pass) and the stream method still had many unsolved problems, Kuznetsov ${ }^{40}$ laid out elaborate and exhaustively detailed plans for a large-scale gasification station at Shakhty. The first proposed commercial station was to have employed numerous panels of coal gasified by the chamber method with storing, and was to have supplied the Artem power station with a 21.6 million $\mathrm{m}^{3}$ of gas per month, with a heating value of 1100 to $1350 \mathrm{kcal} / \mathrm{m}^{3}$.

Apparently, this gasification station never operated. (In 1936, Chekin et a1. ${ }^{41}$ reported that construction was nearing completion. The present authors can find no later reference to the Shakhtiy station.) However, when it became clear that the stream method offered the reliability of a controlled process, the Soviets wasted no time in designing and producing other large scale underground gasification stations using the stream

$*$

We were unable to find cost estimates for the production of energy by the underground coal gasification process. However, Sazonov ${ }^{12}$ stated in 1935 that the process would be economically feasible if the production cost/kcal of heat did not exceed $6 \times 10^{-4}$ kopeks. method, * A station near Tula in the flat brown coal seams of the Moscow Basin was opened in November 1940. It used three vertical holes, three mined channels $70 \mathrm{~m}$ long, and a connecting channe1 $100 \mathrm{~m}$ long. The vertical holes were lined with steel pipes, and the three channels were lined with perforated steel pipes. Using an oxygen-enriched blast, 34 million $\mathrm{m}^{3}$ of gas with an average heating value of $875 \mathrm{kcal} / \mathrm{m}^{3}$ was produced and supplied to a local brick manufacturing plant and to the "Liker P1ant". 42 The station was abandoned when the German invasion neared Moscow in October 1941.

Another station using the stream method was opened in December 1940 in the steeply dipping beds near Lisichansk. Three panels with three shafts each were built. The shafts were separated by $120 \mathrm{~m}$ and the fire drift was mined at the $120 \mathrm{~m}$ level. In the first months a $60 \%$ oxygen enrichment was used to produce gas with a heating value of $1600 \mathrm{kcal} / \mathrm{m}^{3}$. As the channel broadened the heating value dropped. Various operational methods were attempted to maintain the production of gas with a high heating value. From February to September 1941, 40 million $\mathrm{m}^{3}$ of gas were supplied to

\footnotetext{
*Various Russian authors refer to different stations as the "first industrial" or "first semi-industrial" underground coal gasification station.
} 
the Donsoda Factory and then to the Lis-chim-Combinat. ${ }^{37}$ (The station was designed to produce 0.5 million $\mathrm{m}^{3} /$ day.) $)^{43}$ In December 1941, the

German invasion forced termination of the experiment. However, the gasification site was excavated when the station was reopened after the war.

A Belgian reviewer ${ }^{37}$ wrote in 1951 that other stations were also under construction before World War II at the following locations: Novo Kuznets in Siberia, Grischenov in the Donets. Chelyabinsk in the Urals and Kurachovka in the Ukraine. The Soviet author Nusinov, ${ }^{42}$ in his 1941 review, mentioned the latter two stations, but we were unable to find any information concerning industrial or semi-industrial production from these stations.

It was reported in 1941 that in Soviet coal mines about $70 \%$ of the labor was underground, while in the underground gasification stations on 1 y about $15 \%$ of the labor was underground. (When the stream method was used; the underground channels were mined out manually.) The production capacity of a worker at an underground gasification station was about five times that of an ordinary niner (energy equivalent.) 1,44 * $*$ The production capacity of an average Russian miner in the 1930's was reported at various amounts ranging between 30 and $60 \mathrm{t} / \mathrm{mo} .44,45$ Although even the larger figure is very small. by today's standards, the approximate capacity seems wel1-substantiated. 1
Although the Soviets were anxious to bring the underground coal gasification process to industrial size, they recognized the magnitude and complexity of the problems facing them. ${ }^{33}$ Perhaps the most pressing problems were control and automation. To solve these, it was necessary to obtain accurate records of the temperature and positions of the fire front, to develop precise methods of measuring and regulating the quality and quantity of gas produced, 46 and to investigate the physical and chemical changes of the coal and surrounding strata while considering the different geological conditions at various sites.

By 1940 several research projects $^{47,48}$ had been conducted to determine, for example, the "Behavior of the Roof of a Coal Seam in the Presence of Underground Gasification. $" 47$ It was felt that the choice of gasification method should be determined by the geological and hydrogeological features of the site. For example, in areas subject to roof instabilities, the stream method would not be the best choice. ${ }^{25}$ It seemed to be commonly held that a series of boreholes provided the best contact of blast and reacting surfaces and, therefore, it was the most controllable and reliable. 49

(Although this opinion was still common as late as $1953,{ }^{49}$ there were 
apparently no gasification trials based on this method after 1936 . Although it had given the best results at the experimental stage, it was expensive, required much underground labor, and was not well suited for expansion to inductrial size.)

In flat and near-flat seams, caveins near the fireface could completely obstruct the fireface, often resulting in a considerable resource loss. 50 It was suggested that at Tula (Moscow Basin) the gasification process should be conducted at a temperature below the melting point of the ash; thus, the ash would remain porous and help support the roof. Chukanov and Sagaidak, 51 and Lavrov and co-workers $52,53,54$ used their knowledge of the behavior of the high ash coal and of the surrounding strata to produce compelling arguments for incorporating a "filtration gasification" phase in the Moscow Basin project.

Since the earliest work on underground coal gasification, the Soviets had hoped ultimately to eliminate the need for underground labor. Even with in situ methods, some mining was required to create a channel for gasification. However, they hoped nonmining methods of permeability enhancement would be adequate where the native permeability was relatively high, as is the case for the brown coal seams of the Moscow Basin. Thus, when the Tula station was reopened in July 1942 (following the period of wartime evacuation), it was decided not to use underground labor. Boreholes were drilled near the area gasifed by the stream method the year before. These were then joined to the old fire drift by gradually burning through the intervening coal. 36 The method adopted and perfected in the succeeding years at Tula depends in the principle put forward by Betts in his British Patent of 1909. Two holes were drilled, air was blown in one borehole, and a fire was lit in the other. As the intervening coal was heated and dried, shrinkage cracks and fissures developed and the fire moved toward the inlet air hole, forming a highly permeable ash-filled channel. 55

Few details of the early experiments in the Moscow Basin are available.* It is not known when the stream'method was abandoned in flat seams, when the Soviet workers decided on the rectangular pattern employed today, or how quickly they developed a technique for locating and controlling the progress and direction of the fireface. Perhaps it is useful to mention briefly one early suggestion that may help the reader

*In 1957, Leshchiner \& Urtchenko ${ }^{56}$ commented on the dirth of Soviet papers in underground coal gasification published after World War II. 
understand some of the thinking that iffected the early development of no-underground-1abor in situ coal gasification. In 1939, Lavrov and co-workers suggested boring holes and establishing channels on a rectangular pattern (Fig. 14). However, they visualized "filtration gasification," that is, the burn taking place in the coal volume, as opposed to beginning in, and spreading out from, the channels. 53 It is not known whether this method of injecting and withdrawing at the corners of the pattern was ever tried.

The stream method with underground mining continued to be used in the steeply dipping hard coal beds of the

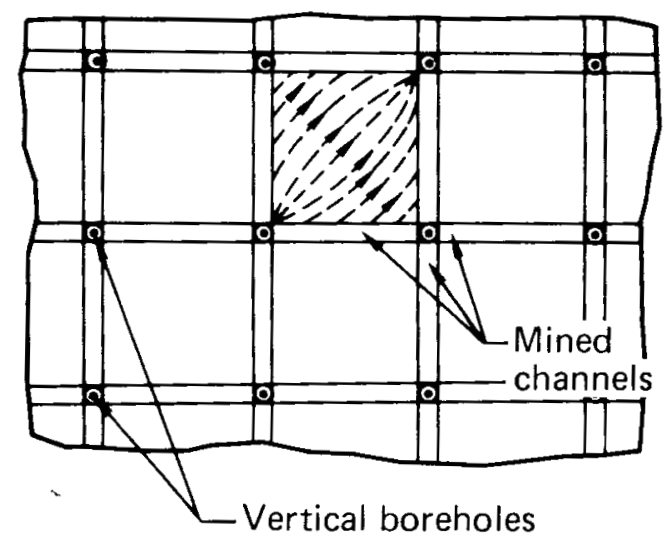

Fig. 14. Plan view of "filtration gasification" method proposed for Moscow region coal.

Donets. Sometime in the 10 yr following World War II, a second set of boreholes was introduced into the design (Fig. 15) to bring the blast closer to the oxidation zone and to
Plan view

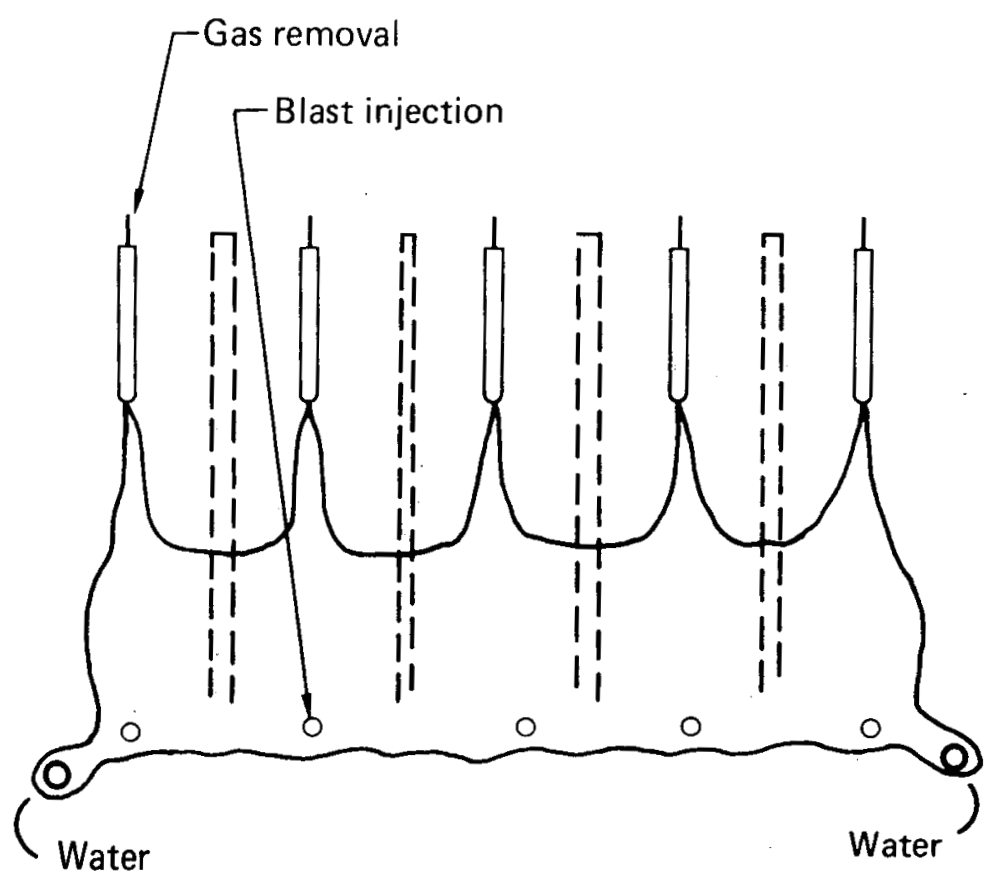

End view

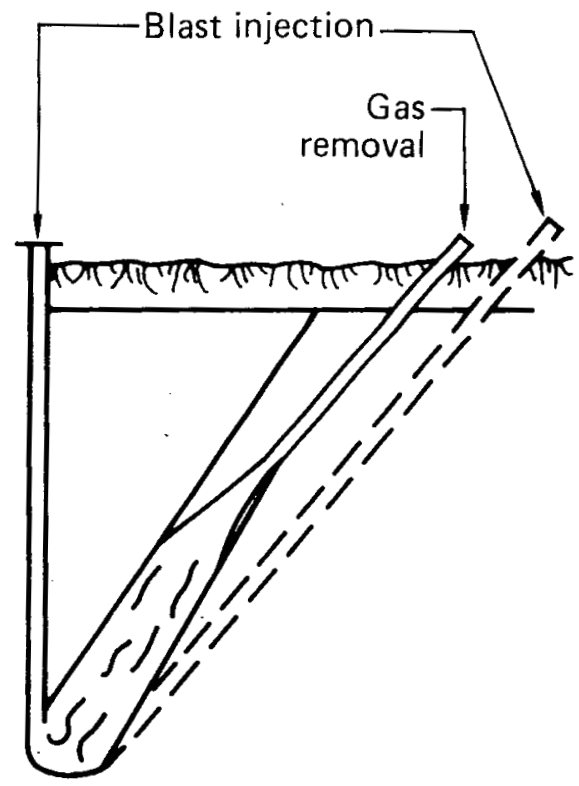

Fig. 15. Modification of stream method modification of underground gas generator for steeply dipping coal beds. 
lower the hydraulic resistance that reduced the blast pressure at the fireface. ${ }^{21}$ Note that by bringing the blast through the overburden or underburden into the bottom of the panel to be gasified, channeling and bypass (loss of resource) are largely eliminated, and therefore the need for perforated pipes is also eliminated. Although experiments with hydraulic fracturing were conducted at Gorlovka before the war, and directional drilling was used in the steeply dipping seams at Lisichansk since 1948, the Soviets continued to mine the horizontal fire channel until about 1958. 57 (Apparent1y, electrolinking, the use of electricity to form the highly permeable channel, was first tried in the United States by Forrester and Sarapuu at the Missouri School of Mines. 58 While the Soviets reported some successful results with electrolinking in the brown coal seams of the Moscow Basin, ${ }^{59}$ Shmarev et al. 60 report that electrolinkage was not commerically applicable due to the "complicated arrangements required and the number of adverse features encountered"). 60 Today the boreholes in the steeply dipping hard coal seams of Yuzhno Abinsk are joined by hydraulic fracturing, pneumatic fracturing, or directional drilling. Although details concerning the use of slanted boreholes are given in Ref. 19, it should be mentioned that slanted boreholes were used both in the flat seams of the Angren ${ }^{*}$ and the Moscow Basin brown coals, and in the Yuzhno Abinsk ${ }^{*}$ bituminous seams, to eliminate subsidence damage to the blast and exhaust pipes.

\footnotetext{
* These two stations were opened after the developmental period covered in this report. They are operational today and will be discussed in future reports.
}

\section{Organizations and Institutes}

The development of underground coal gasification to its present design has taken place largely in the field experiments described above. However, various laboratory and theoretical studies of the physical and chemical processes involved have been conducted in numerous institutes throughout the Soviet Union. A history of the development of underground coal gasification would be incomplete without at least a partial list of the various organizations, institutes, and laboratories that have contributed to the present understanding of the process.

A special commission on the underground gasification of coal was formed 
in the early $1930^{\prime}$ 's to organize the original research, and the State Trust, Podzemgaz, was established in 1933 as the experimental branch. Before the war, theoretical and laboratory experiments were conducted at the Donets Institute of Coal Chemistry and at the Power Engineering Institute of the Academy of Sciences. ${ }^{48}$ In addition, engineers at the underground gas sites were conducting theoretical studies of various aspects of the process. 61

After World War II several institutes of the Academy of Sciences were assigned studies on different aspects of underground gasification: The Institute of Fuel Minerals studied the use of oxygen and steam blasts, 62 and the Mining Institute, Automatics and Telemechanics Institute, and the Hydrogeological Laboratory studied gas flow and leakage problems. 63,64,65 In 1949 , a special institute, VNII Podzemgaz (Union Scientific Research Institute Podzemgaz), ${ }^{66}$ was created to conduct research and planning.

Until 1957, the State Trust Podzemgaz was under the Ministry of Coal. When this Ministry was dissolved at the federal level and reestablished in the various autonomous republics in 1957, Podzemgaz was retained at the federal level and attached to the Directorate General of Gas, which functioned directly under the Council of Ministers of the
Soviet Union. After that time, Podzemgaz centralized and coordinated the Moscow Institute (VNII Podzemgaz), and Stalino Institute of Studies and Projects, as well as the active underground gasification stations and those under construction. It also collaborated with the specialized institutes of the Academy of Sciences, which coordinates all scientific research in the USSR. The Moscow Institute for Underground Gasification (VNII Podzemgaz) directed basic research and followed the field tests, analyzing and interpreting results. By 1959, it had several laboratories conducting research on underground coal gasification.

"The Department of Mines was interested in exploratory work (with boreholes or mined channels on gasified panels, ground movements, rock behavior, and filling of the gasified space. The department of 'Hydrology and Geology' carried out surveys and studied methods for draining the sites before ignition and during operation. Two 'Gasification' departments specialized in the study of brown coal and hard coal, respectively. These departments developed techniques of underground linking and gasification and studied the reaction mechanism and the influence of certain variables. One department was cievoted to electro-linking, another to the improvement of methods for remote- 
control drilling. An aerodynamics department studied questions pertaining to gas flow and the influence of turbulence (small-scale models). There was also a department specializing in remote control and automation of operations. Finally, an economics department determined the profitability of proposed methods or active stations, and an information department followed closely al1 1iterature published abroad." 57

The Stalino Institute of Studies and Projects, GIPRO Podzemgaz, located at Stalino on the eastern border of the Ukraine, planned the large scale projects. In addition, it examined problems related to gas transportation and usage. For example, "This institute developed burners that stabilize a flame of $800-900 \mathrm{kcal} / \mathrm{m}^{3}$ gas and permit the use of gas from underground gasification for household appliances. The Institute supplied data for the design of two gas turbines at Schatsky (12 MW each) and studied the heating of Hoffman brick ovens by gas from underground gasification. It prepared the plans for the stations at Schatsky, Angren and Kamensky, ${ }^{*}$ as we1l as the projects for future and more powerful stations..." 57

\footnotetext{
* The Kamensky station was opened after the developmental period covered in this report. It was built to gasify anthracite but there seems to be only references to production there. See Ref. 67.
} 


\section{Appendix A \\ Basic Principles of Coal Gasification*}

The objective of underground coal gasification is to convert coal into a combustible gas by conducting the appropriate chemical process underground. Air, and sometimes oxygen enriched air, is used to partially combust the coal to produce this gas. During gasification, hot gases from the flame front usually heat the coal to a high temperature in a reducing environment before it is consumed by oxidation reactions. When the coal is heated, it undergoes thermal decomposition and releases various chemical products into the gas stream. These chemical products, known as pyrolysis products, are composed of methane, ethane, and other hydrocarbons with a heating value greater than that of $\mathrm{H}_{2}$ or $\mathrm{CO}$. In both surface and underground coal gasification, the pyrolysis products greatly affect the composition of the product gas:

In most coal gasification operations, the oxidation reactions occur not between oxygen and coal, but rather between oxygen and char (the end product of pyrolysis, primarily carbon). Based on laboratory and in-situ experiments with the coal gasification process, the Soviet

* See Ref. 19 for a complete description of these basic principles. scientists published the following summary of the sequence of reactions. 55

"The oxygen of the air, coming into contact with part of the carbon channel which is heated beyond the temperature of combustion, reacts with the carbon on the surface of the channel and forms oxides of carbon according to the equations $\mathrm{C}+\mathrm{O}_{2}$ $=\mathrm{CO}_{2}$ and $2 \mathrm{C}+\mathrm{O}_{2}=2 \mathrm{CO}$. The resultant carbon dioxide would be replaced on the carbon channel by carbon monoxide according to the equation $\mathrm{CO}_{2}+\mathrm{C}=2 \mathrm{CO}$. Therefore in a cross section of the channel the greatest concentration of oxygen in the gas current will arise along the axis of the channel, and the greatest concentiation of carbon monoxide will be on the walls. Depending on the difference in the concentrations and also on possible turbulence of the current of gases, the resultant carbon monoxide spreads from the coal surface towards the oxygen which comes from the volume of gas towards the coal surface. On meeting the oxygen of the air, the carbon monoxide burns into carbon dioxide according to the reaction $2 \mathrm{CO}+\mathrm{O}_{2}=2 \mathrm{CO}_{2}$. The burning of the carbon monoxide leads, in the first place, to an increase in the carbon dioxide in the gas, and secondly hinders penetration, by the 
free oxygen to the carbon surface of the channe1. Gradually, along a certain length of the channel, the free oxygen in the air is practically al1 used up in burning carbon monoxide, and the content of carbon dioxide in the gas reaches its maximum. Further along the line of the draft in the channel only the reduction of carbon dioxide takes place, and with this, the concentration of $\mathrm{CO}_{2}$ is reduced and that of carbon monoxide increased. The oxidation and reduction zones are divided along the length of the channel. In the first zone oxidation reactions on the surface of the carbon, as well as in the volume of the gases, predominate, and in the second zone reduction reactions taking place on the surface of the carbon predominate. It was noted that the greater the diameter of the channel, the longer were the zones obtained, and the more intensive the mixing of the gas currents, the shorter became the zones.

"Having examined the process of gas formation in a channel with the use of a current of air, we see that in quality it is identical with the process of gas formation in a bed of coke. This is explained by the fact that in both processes not only do the same reactions take place but they depend on the same factors. In essence, a bed of fuel may more or less be regarded as a system of parallel channels penetrating the bed between the pieces of fuel, through which passes the draft and then the gas products resulting from the reactions. These channels have a variable section in length. The axes are not straight lines but wavy ones; the channels are not isolated from each other but are connected. The basic process of gas formation takes place as a result of the interaction between the hard carbon walls of these channels formed by the surfaces of separate pieces of fuel and the moving gas current passing along the channels. In these channels together with the direct interaction of the oxygen of the air with the carbon of the oxygen of the air with the carbon of the surfaces of the pieces of fuel, a formation of two oxides of carbon $\mathrm{CO}_{2}$ and $\mathrm{CO}-$ also takes place. On the surface of the fuel $\mathrm{CO}_{2}$ is replaced by $\mathrm{CO}$, which is diffused from there to the axis of the channels, and the oxygen, contrariwise, is diffused from the axis of the air current towards the fuel surface. When the oxygen contacts the carbon monoxide the latter burns into carbon dioxide, and in this way $\mathrm{CO}_{2}$ is the carrier of the oxygen atoms from the volume of gases to the surface of fuel.

"The scheme of gas formation is in principle the same for a single channel as for a series of parallel 
channels in a bed. However there are differences in the two processes.

These differences concern in the first place the area of the separate zones of the process. If the average diameter of the pieces of coke is taken as the standard in the fuel bed, its diameter as that of the channe1, then the length expressed by these standard measures will be called the relative length of the zones. In the bed, the length of the oxidation zone is equal to three times the average diameter of the pieces of fuel and the dimension of the reduction zone is three or four times as great as the size of the oxidation zone. In a straight channel the relative size of the zones is many times greater than in a bed. This is explained by the fact that in a bed of fuel where the channels twist and turn a great deal and become wider and narrower in turn, the intensity of the mixing of the gas current is many times greater than that in a straight channel of constant diameter.

"One more circumstance should be noted. The speed of the reduction, reactions, which usually take place in the kinetic phase of reaction of transitional phase near it, is very sensitive to the temperature of the process. Therefore the higher the temperature the greater the speed of the reduction of $\mathrm{CO}_{2}$ and the shorter the reduction zone which conversely is greatly lengthened by the falling temperature. In temperatures of less than $700^{\circ} \mathrm{C}$ the reduction process can be practically excluded."

"If char is combusted stochiometrically in pure oxygen in the absence of heat losses, burn temperatures as high as $3000 \mathrm{~K}$ would be expected. ${ }^{68}$ This is far in excess of the temperature needed to produce a reaction product of essentially all CO. However, such a reaction system is inefficient because a large fraction (approximately 25\%) of the heat of combustion of the char is expended for further heating of the co rather than for producing more combustible product. Therefore, steam is added to utilize this excess heat of reaction and to produce more combustible gas:

$\mathrm{H}_{2} \mathrm{O}+\mathrm{C} \rightarrow \mathrm{CO}+\mathrm{H}_{2}-31.4 \mathrm{kcal} / \mathrm{g}-\mathrm{mol}$.

"In underground coal gasification systems operating below the water table, water is added unavoidably into the reaction zone by leakage from the surrounding formations. In fact, the Soviet experience in the use of air for underground gasification has revealed that the natural water intrusion rate can easily exceed the optimum rate and result in reduced efficiency of the process due to excessive cooling of the reaction

\footnotetext{
* This is taken from Ref. 55. For a more complete description, the reader is referred to Ref. 19.
} 
zone. 69 When oxygen is used instead of air, the cost and quantity of oxygen required is a major concern. In this case, the addition of steam not only improves the energy efficiency of the process by utilizing the excess heat $\left[\mathrm{CO}_{2}=\mathrm{CO}_{2},\left(\mathrm{CO}_{2}\right.\right.$ $=2 \mathrm{CO}, 2 \mathrm{CO}+\mathrm{O}_{2}=2 \mathrm{CO}_{2}$ are all exothermic] but also minimizes the amount of oxygen required per ton of coal gasified, significantly improving the economics of the process. 68
"A similar means of effectively utilizing the excess combustion energy is accomplished by reducing $\mathrm{CO}_{2}$ to $\mathrm{CO}$ :

$\mathrm{CO}_{2}+\mathrm{C} \rightarrow 2 \mathrm{CO}-41.2 \mathrm{kcal} / \mathrm{g}-\mathrm{mol}$.

In fact, this reaction routinely occurs in long gasification channels as the $\mathrm{CO}_{2}$ formed upstream is reduced to CO further downstream. $21 " *$

${ }^{*}$ Reprinted from Ref. 19. 


\section{References}

1. L. J. Jolley, and N. Booth, "The Underground Gasification of Coal. Survey of the Literature," Fuel 24, 31-37, 73-79 (1945).

2. H. Goergen, and E. Kurtulus, "Underground Gasification Processes," Gluckauf-Forschungshefte 34, 199-202 (1973) [English trans1.: Lawrence Livermore Laboratory, UCRL-10866].

3. C. W. Siemens, "On the Regeneration Gas Furnace as Applied to the Manufacture of Cast Stee1," Chemical Society (London) Transactions 21, 279-310 (1868).

4. J. Rauk, "Underground Gasification of Coal," Chemik (Gliwice) 16, 120-124 (1963) [English trans1.: Lawrence Livermore Laboratory, UCRL-11103].

5. N. Volkov, "One of the Great Victories of Soviet Technology," Front Nauki i Tekniki 6 , 57-62 (1938) [English trans1.: . Lawrence Livermore Laboratory, UCRL-11034].

6. L. E. Zhuraleva, and E. M. Danilova, "Underground Gasification of Coal," Khimiya $v$ Shkole 13, 3-5 (1958) [English trans1.: Lawrence Livermore Laboratory, UCRL-11087] .

7. A. B. Chernyshev, "Underground Gasification of Coal and the Tasks of the Academy of Sciences of the USSR," Vestnik Akademii Nauk SSSR 1938 44-99 (1938) [English trans1.: Lawrence Livermore Laboratory, UCRL-11027].

8. A. G. Betts, Improved Process for Utilizing Unmined Coal, British Patent 21674 (Sep. 22, 1909).

9. Anon., "Smoke Abatement Exhibition," The Gas World, 422-428 (1912).

10. V. S. Kulebakin, "Underground Gasification of Coal - Advanced Soviet Technology," Avtomatika i Telemekhanika 4, 3-6 (1939) [English trans1.: A. D. Litt1e G-168].

11. G. D. Bakulev, "Ekhonomicheskiy Analiz Podzemnoi Gazifikatsii," Academy of Sciences USSR, 133 (1957) [Bureau of Mines Information Circular 8069].

12. N. I. Sazonov, "Summary of the First Experimental Results of Subterranean Gasification of Coals," Khim. Tverd. Top: $\underline{6}, 17-28$ (1935) [Eng1ish trans1.: A. D. Little G-207].

13. Anon., "Electricity Direct from Coa1," Electrical Review and Western Electrician 60, 692 (1912).

14. "Industry-Agronomy-Public Works," Revue Scientifique 4, 116-117 (1912).

15. Anon., "Memorial to the Late Sir William Ramsey," Nature 98, 197 (1916). 
16. I. P. Kirichenko, "Results and Prospects in the Sector of Underground Gasification of Coa1," Ugol' 30, 7-15 (1936) [English trans1.: Lawrence Livermore Laboratory, UCRL-11026].

17. I. P. Kirichenko, "First Survey of the Work in the Area of Underground Gasification," UgoI 101, 90-101 (1934) [English trans1.: A. D. Little, G-162] .

18. I. P. Kirichenko, and V. S. Ton, "Underground Coal Gasification at the Lisichansk Mine," Gornyi Zhumal 111, 10-9 (1935) [English trans1.:

A. D. Little, G-156].

19. D. W. Gregg, and D. U. Olness, Basic Principles of Underground Coal Gasification, Lawrence Livermore Laboratory, Rept. UCRL-52107 (1976).

20. N. I. Sazonov, "Results of Experiments on Underground Gasification of Coal," Khim. Tverd. Top. 6, 861-869 (1935) [Eng1ish trans1.:

A. D. Little, G-203].

21. P. V. Skafa, "Underground Gasification of Coa1," Gosudarstvennoe Nauchno Tekhnicheskoe Izdatelstvo Literatury Po Gornomu DeZu, (1960) [English trans1.: Lawrence Livermore Laboratory, UCRL-10880].

22. D. M. Arienenkov, and L. M. Markman, "Underground Gasification of Coal," Knizhnoe Izdatelstvo STALINO-DONBASS (1960) [English transl.: Lawrence Livermore Laboratory, UCRL-11007].

23. I. P. Kirichenko, and V. S. Ton, "Experiments in Underground Coal Gasification at the Lisichansk Mine (Part 2)," Gomyi Zhurnal 111, 10-21 (1935) [English trans1.: Lawrence Livermore Laboratory, UCRL-11012].

24. I. P. Kirichenko, and V. S. Ton, "Experiments in Underground Coal Gasification at Lisichansk Mine (Part 3)," Gomyi Zhumal 111, 5-14 (1935) [English trans1.: Lawrence Livermore Laboratory, UCRL-11013].

25. S. I. Buyalov, "Principles of Underground Gasification," UgoZ 11, 17-24 (1938) [English trans1.: A. D. Little G-159].

26. P. V. Skafa, "Principal Results of Experimental Work on the Underground Gasification of Brown Coal in the USSR," in Proc. World Power Conference, Belgrade [English transl.: Lawrence Livermore Laboratory, UCRL-10958].

27. B. F. Grindler, "What Really Happened at Leninsk," Ugol' Vostoka $\underline{5}$, 14-15 (1935) [English transl.: Lawrence Livermore Laboratory, UCRL-11148] • 
28. V. Palvelev, "Underground Gasification of Pillar Coal," Ugol' Vostoka $\underline{5}$, 17-18 (1935) [English transl.: Lawrence Livermore Laboratory, UCRL-11149].

29. V. Alekseev, "Let's Make Prokopevsk a Gasification Center," Ugol' Vostoka 4, 28-30 (1934) [English trans1.: Lawrence Livermore Laboratory, UCRL-11010].

30. B. F. Grindler, "Second Cycle of Tests on Underground Gasification of Coal Kuzbass," Ugol' Vostoka 5, 11-14 (1936) [English transl.:

Lawrence Livermore Laboratory, UCRL-11031].

31. P. Makhin and P. Botin, "Second Trial of Underground Gasification of Coal at Leninsk," Ugol' Vostoka 5, 43-48 (1935) [English transl.: Lawrence Livermore Laboratory, UCRL-11011].

32. L. E. Zhuraleva, and E. M. Danilova, "Underground Gasification of Coal," Khimiya v Shkole 13, 3-5 (1958) [English trans1.: Tawrence Livermore Laboratory, UCRL-11087].

33. D. M. Arinenkov, "Underground Gasification of Coal in Situ," Vestnik Inzhenerov i Teknikov 12, 758-760 (1938) [English trans1.: Lawrence Livermore Laboratory, UCRL-11086].

34. A. Ignatieff, "Underground Gasification of Coal: Review of Progress." Trans 2. Canadian Inst. Min. and Met. Eng. 52, 265-271 (1949).

35. F. Stuart Atkinson, "Underground Gasification of Coal in the U.S.S.R.," Colziem Engineering, pp. 119, 120, 131 (1937).

36. V. A. Matveev, "A Brief Report of Results and of the Most Pressing Problems in t:s Field of Underground Gasification of Coa1," Podzemnaya Gazifikatsiya Uglei 4-26 (1957). [Eng1ish trans1.: National Coal Board, Great Britain, Trans1. A-1408/SEH (19.57)].

37. Inichar, "Underground Gasification [n Various Countries (Part 1)," Annales des Mines de Belgique 50, ¿l-68 (i-ii) [i iglish transl.:

Lawrence Livermore Laboratory, UCRL-11095].

38. V. I. Belov "Regulation of the Quality of Gas From Underground Gasification (of Coal) by Blowing With Periodically Changing Velocity." Podzemnaya Gasifikatsiya UgZei 2, 90-92 (1957) [Humphreys and Glasgow Trans1. by Madame Botchorskaya (1958)].

39. N. Beniaminow, "Underground Gasification of Coal in the U.S.S.R.," The Gas World 114, 101 (1941). 
40. A. S. Kuznetsov, "Preparation For an Industrial Trial of Underground Gasification of Anthracites in the Shakhty Region," Ugol 125, 87-96 (1936) [English trans1.: Lawrence Livermore Laboratory, UCRL-11043].

41. P. A. Chekin, A. I. Semenoff, and J. S. Galinker, "Underground Gasification of Coals," The Colliemy Guardian 62, 1193-6 (1936).

42. G. O. Nusinov, "The Subterranean Gasification of Coa1," Canadian Chem. and Process Ind. 30, 29-32 (1946).

43. H. Rose, "Underground Gasification of Coa1," American Gas Journal, 28 (1944).

44. E. T. Wilkins, "The Underground Gasification of Coal: Some Considerations of Available Information," Fuel Economy Review 23, 14-18, 58 (1944).

45. L. T. Minchin "Underground Gasification in Italy and Russia," Gas Wortd 129, 931-932 (1948).

46. A. C. Dunningham, "Underground Gasification of Coal," Coke 13, 277-280 (1951).

47. S. I. Buyalov, "Behavior of the Roof of a Coal Seam in the Presence of Underground Gasification," Izv. Akad. Nauk. SSSR, Otd. Tekhn. Nauk $\underline{8}$, 51-65 (1940) [Eng1ish trans1.: Lawrence Livermore Laboratory, UCRL-11036].

48. M. A. Gerdov, "Some Results of a Thermal Investigation of Rocks Enclosing Coal Seams for the Purpose of Studying Their Behavior During Underground Gasification of Coa1," Izv. Akad. Nauk SSSR, Otd. Tekhn. Nauk $\underline{8}, 67-82$ (1940) [English trans1.: Lawrence Livermore Laboratory, UCRL-11035].

49. "Underground Gasification, II. Report of the Organization for European Economic Cooperation Technical Assistance Mission," Gas World 138, 508-511 and 585-589 (1953).

50. I. V. Efremenko, and N. N. Talyzin, "Underground Gasification of Coal - A New Branch of Socialist Industry," Problemy Ugoz 'noi Promyshzennosti, $v$ Tret'em Pyatiletii, 94-122 (1940) [English trans1.: Lawrence Livermore Laboratory, UCRL-10873].

51. Z. F. Chukhanov, and M. Ya. Sagaidak, "On the Underground Gasification of Moscow-Basin Coal and Shales," Izv. Otd. Tekhn. Nauk. 8, 3-18 (1939)

[English transl.: Lawrence Livermore Laboratory, UCRL-11082]. 
52. N. V. Lavrov, R. N. Pitin, and I. L. Farberov, "Underground Gasification of Moscow Basin Coals in a Filtration Channel," Izv. Akad. Nauk SSR, Otd. Tekhn. Nauk 4, 11-18 (1940) [English transl.: Lawrence Livermore Laboratory, UCRL-11024] •

53. N. V. Lavrov, I. L. Farberov, and R. N. Pitin, "Underground Gasification of Moscow-Region Coal," Vestnik Inzhenerov i Tekhnikov 423-424 (1939)

[Eng1ish trans1.: Lawrence Livermore Laboratory, UCRL-11081].

54. N. V. Lavrov, I. L. Farberov, and R. N. Pitin, "Method of Underground Gasification of Coa1," Vestnik Inahenerov $i$ Tehnikov 277-279 (1940)

[English transl.: Lawrence Livermore Laboratory, UCRL-11084].

55. R. N. Pitin, and I. I. Farberov, "Podzemnaya Gasifikatsiya," IzdateZ. Akad. Nauk. S.S.S.R. (1955) [Humphreys and Glasgow Transl. by

P. R. Wilson (1958)].

56. R. Ye. Leshchiner, and Urtchenko, "Increase the Scientific and Technological Information of the Underground Gasification," Podzemnaya Gazifikatsiya Uglei 88-89 (1957) [U.S. Bureau of Mines Trans1. 151].

57. 0. De Crombrugghe, "La Gazeification Souterraine en U.S.S.R.," Ann. mines Belgigue 478-534 (1959) [U.S. Bureau of Mines Trans1. 1360 (1961)].

58. J. D. Forrester, and E. Sarapuu, Process of Underground EZectrocarbonization, Univ. of Missouri, Sch. Mines and Met., Tech Ser. (1952).

59. A. Gibb and Partners The Underground Gasification of Coal, (Pittman and Sons, London, 1964).

60. A. T. Shmarev, S. N. Yatrov, and S. G. Galustov, "Use of Hydrauli= Rupture of Seams in Underground Gasification of Solid Fuels.," Mekhanizatsiya Tmudoyemk. i Tiazhel. Rabot 22-24 (1957) [U.S. Bureau of Mines Trans1.].

61. D. M. Arinenkov, "Loss of Gas into the Rocks and Into the Seam Being Gasified in Underground Coal Gasification," Vestnik Inzkenerov i Tekhnikov 194-197 (1939) [English transl.: Lawrence Livermore Laboratory, UCRL-11045].

62. N. Z. Brushtein, and S. P. Golger, "Testing the Process of Underground Gasification of Coal in a Steam-Oxygen-Air Draft," Trudy Vsesoyuznogo Nauchn-Issledovatel' skogo Instituta Podzemnoi Gazifikatsii Uglei 64-66 (1961) [English trans1.: Lawrence Livermore Laboratory, UCRL-11096]. 
63. I. A. Charnyi, "Gas Filtration in a Coal Bed (Concerning Leaks of Gas and Blast in the Underground Gasification of Coal Beds)," Izvestiya AN SSSR, otdeZeniye Tekhnicheskikh Nauk 2, 131-141 (1947) [English trans1.: Lawrence Livermore Laboratory, UCRL-11153].

64. A. S. Predvoditelev, "Gas Formation During the Combustion of Coal in the Bed," Izvestiya AN SSSR, Otdeleniye Tekhnicheskikh Nauk 1329-1340 (1947) [English trans1.: Lawrence Livermore Laboratory, UCRL-11154].

65. A. M. Terpigorev, "Proposals and Deliberations at the Debate 'On the Position and Future Development Trends of Science With Regard to Underground Gasification of Coal' which Took Place in the Soviet Academy of Sciences From 23 to 28 May 1957," Podzemaya Gazifikatsiya Uglei 3 , 7-12 (1957) [Humphreys and Glasgow Trans1. 109 by P. R. Wilson (1958)].

66. N. V. Lavrov, "O Podzemnoy Gazifikatsii Uglei," Vestnik Akad. Nauk S.S.S.R. 6, 62-63 1954 [U.S. Bureau of Mines Trans1.].

67. T. M. Guschina, "Physicochemical Properties of Lean Coals in the Area of the Kamensk Podzemgaz Station," Tr. Vses. Nauchn.-Issled. Inst. Prdzemn. Gazifikatsii Uglei 21-25 (1965) [English transl.: Lawrence Livermore Laboratory, UCRL-11053].

68. C. Thorsness, Lawrence Livermore Laboratory, private communication (1975).

69. R. I. Antonova, I. S. Garkusha, E. G. Gershevish, E. V. Kreinin, N. V. Lavrov, D. K. Semenenko, and N. A. Fedorov, "Some Regular Parameters of Underground Coal Gasification," Khimiya tverdogo topliva 86-96 (1967.) [English trans1.: Lawrence Livermore Laboratory, UCRL-10804].

$M D / j n / j y / 1 m c / j f$ 